\begin{abstract}
HETEROCYCLES, Vol. 93, No. 1, 2016, pp. 164 - 184. (c) 2016 The Japan Institute of Heterocyclic Chemistry Received, 18th August, 2015, Accepted, 14th September, 2015, Published online, 6th October, 2015
\end{abstract} DOI: $10.3987 / C O M-15-S(T) 14$

\title{
NEW GAS-PHASE DOMINO PROCESSES LEADING TO BENZOPYRANONES AND BENZOFURANS
}

\section{R. Alan Aitken* and Da Chang}

EaStCHEM School of Chemistry, University of St Andrews, North Haugh, St Andrews, Fife, KY16 9ST, UK; E-mail: raa@st-and.ac.uk

\begin{abstract}
A new domino approach to flavones by gas phase pyrolysis of $\beta, \gamma$-dioxophosphonium ylides containing a 2-methoxyphenyl group is frustrated by unexpected and novel decarbonylation of the intermediate flavon-3-yl radical leading to 2-phenylbenzofuran. Alternative approaches based on dioxolane protection of one carbonyl, or selective elimination in $\beta, \beta^{\prime}$-dioxo or $\beta$-oxo- $\beta^{\prime}$-thioxo ylides were not successful, but pyrolysis of a $\beta$-oxo- $\beta$ '-phenylimino ylide did give the required domino reaction leading to a protected benzopyranone in moderate yield.
\end{abstract}

\section{INTRODUCTION}

One of the most powerful general strategies for synthesis of fused-ring heterocyclic compounds is the domino or cascade reaction approach in which functionality created in one step is used for subsequent cyclisation processes. ${ }^{1,2}$ Although most such reactions are conducted in solution, the use of gas-phase conditions is becoming increasingly common and a recent review of the use of flash vacuum pyrolysis (FVP) in the synthesis of heterocycles includes many examples. ${ }^{3}$ In previous work we have developed a range of domino methods involving FVP of suitably substituted carbonyl-stabilised phosphonium ylides. Although domino approaches to alkenylnaphthalenes ${ }^{4}$ and substituted 1,3-dienes ${ }^{5}$ have also been described, the majority of work has focused on ylides of general structure 1 or $\mathbf{2}$ (Scheme 1). Thermal extrusion of $\mathrm{Ph}_{3} \mathrm{PO}$ generates an alkyne function and, under the same conditions, the group XR loses the radical $\mathrm{R}^{\circ}$ to give intermediate 3 which is set up to undergo a 5-endo-dig cyclisation giving a new heterocyclic radical 4. In simple cases this forms stable products by hydrogen atom abstraction, either from the group Y or the environment, to afford benzofurans and benzothiophenes $(\mathrm{XR}=\mathrm{OMe}$ or $\mathrm{SMe}){ }^{6}$ but incorporation of a suitable group $\mathrm{Y}$ joined by a tether allows construction of tricyclic systems $\mathbf{5}$ by further addition or substitution events. This has been used to construct tricyclic and tetracyclic fused ring systems containing furan and thiophene, ${ }^{7,8}$ and nitrogen can also be introduced either by starting from a pyridine analogue of $\mathbf{1}$ 
pyridine analogue of $\mathbf{1}$ or $\mathbf{2}$ leading to thieno[2,3-b]pyridines, ${ }^{9}$ or having $\mathrm{X}=\mathrm{NMe}$ which allows access, depending on the nature of $\mathrm{Y}$, to carbazoles or quinolines. ${ }^{10}$ All the studies so far have relied on the key cyclisation of $\mathbf{3}$ to $\mathbf{4}$ forming a five-membered ring.<smiles>[Y]CCC(=O)C(=P)c1ccccc1[Y2]</smiles>

1

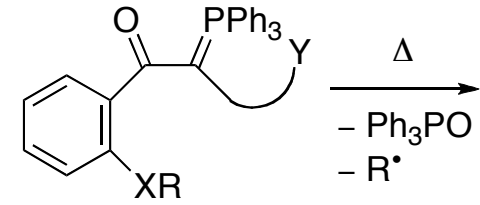

2<smiles>[Y]CCC#Cc1ccccc1[X]</smiles>

3

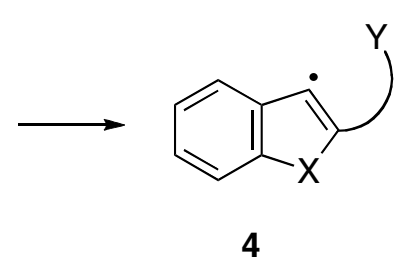<smiles>[X]c1ccccc1-c1ccccc1</smiles>

5

Scheme 1. General approach to domino reactions based on phosphonium ylide pyrolysis

An obvious extension to this chemistry would be to insert a spacer between the benzene ring and alkyne and in this paper we describe approaches to benzopyranone synthesis involving generation and cyclisation of analogues of $\mathbf{3}$ with $\mathrm{X}=\mathrm{O}$ and a carbonyl group between the benzene ring and the triple bond. Benzopyranone systems such as the flavones occur widely in nature and are of considerable biological and medicinal importance, ${ }^{11}$ making new methods for their synthesis highly desirable.

\section{RESULTS AND DISCUSSION}

The general retrosynthetic approach to a flavone involves disconnection of product $\mathbf{6}$ to the radical precusor 7 (Scheme 2) which could in principle be generated by FVP of either of the isomeric ylides 8 or<smiles></smiles><smiles></smiles><smiles>C=C</smiles><smiles></smiles>

7<smiles>C=C</smiles><smiles>COC1=C(C(=O)C(=P)c2ccccc2)C(=O)c2cc[R7]cc21</smiles>

9

Scheme 2. Approaches to flavones from carbonyl-stabilised phosphonium ylides 
9. However compound $\mathbf{8}$ seems much more promising since extrusion of $\mathrm{Ph}_{3} \mathrm{PO}$ can only occur in the desired sense, whereas unsymmetrical $\beta, \beta^{\prime}$-dioxo ylides such as 9 are known to eliminate $\mathrm{Ph}_{3} \mathrm{PO}$ in both possible directions to give a mixture of isomeric alkynes. ${ }^{12}$ The only previous FVP study of $\beta, \gamma$-dioxo ylides involved compounds of the type $\mathrm{Ph}_{3} \mathrm{P}=\mathrm{CH}-\mathrm{COCOR}$ and did give the alkynes $\mathrm{HC} \equiv \mathrm{CCOR}$ for $\mathrm{R}=$ OMe and OEt but not for $\mathrm{R}=\mathrm{Ph} .{ }^{13}$ We therefore decided to start by preparing the parent compound $\mathbf{8}\left(\mathrm{R}^{1}\right.$ $\left.=\mathrm{R}^{2}=\mathrm{H}\right)$ as a precursor to flavone.

The synthesis of ylide 14 (Scheme 3) starts from the $\alpha$-oxo ester 10, which was prepared by a literature method ${ }^{14}$ involving lithium/halogen exchange of 2-bromoanisole with butyllithium followed by reaction with diethyl oxalate. The product showed good agreement with literature spectroscopic data, ${ }^{15}$ and was readily hydrolysed to the known $^{16}$ carboxylic acid $\mathbf{1 1}$ with sodium hydroxide. Following the normal method for preparation of carbonyl-stabilised ylides, the acid $\mathbf{1 1}$ was converted into the unstable acid chloride in excellent yield 12 using oxalyl chloride, and this reacted with two equivalents of benzylidenetriphenylphosphorane with "transylidation" ${ }^{17}$ to give the desired ylide 14. The yield of the final step was rather low so we investigated the alternative use of the $\mathrm{N}$-acylbenzotriazole $\mathbf{1 3}$ whose use for ylide acylation has been described by Katritzky. ${ }^{18}$ Although the acylation using this method did indeed give a higher yield and required only one equivalent of ylide, the preparation of $\mathbf{1 3}$ was very low yielding, making the acid chloride route preferable overall.

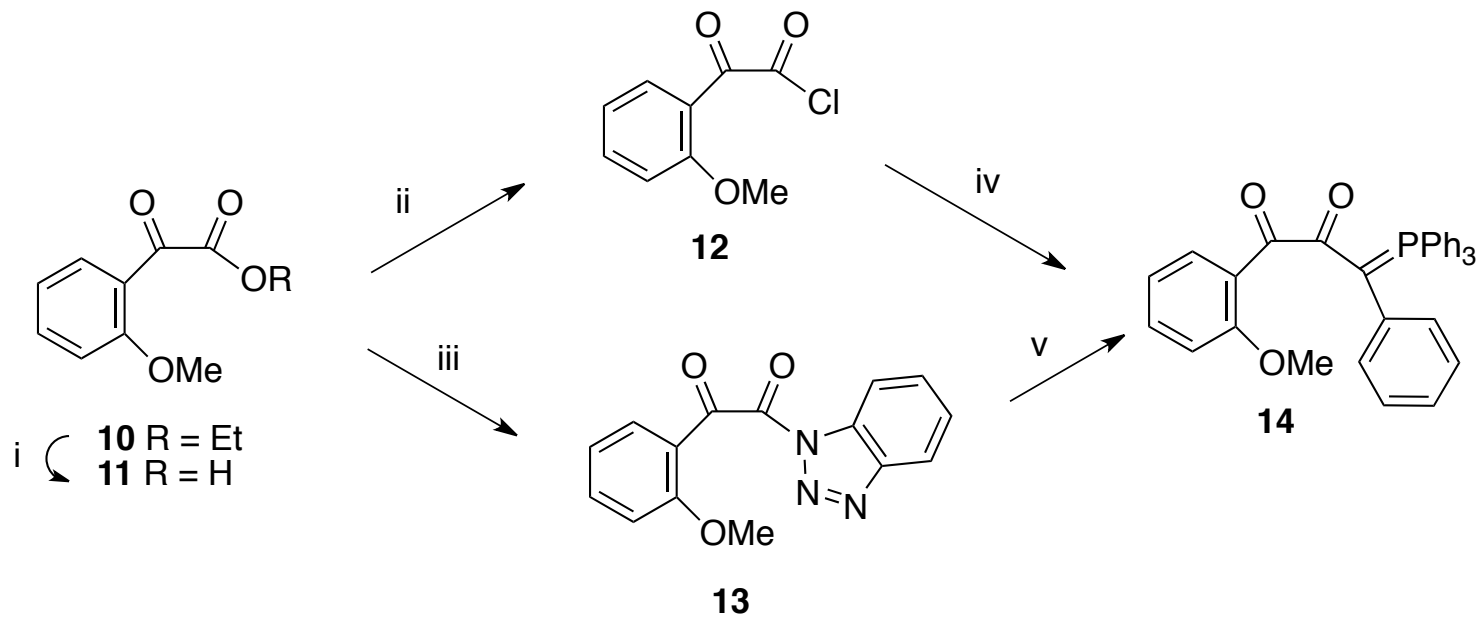

Reagents and yields: i, aq. $\mathrm{NaOH}, 65 \%$; ii, $\mathrm{ClCOCOCI}, 94 \%$; iii, 4 eq. benzotriazole, $\mathrm{SOCl}_{2}$, $11 \%$; iv, 2 eq. $\mathrm{PhCH}=\mathrm{PPh}_{3}, 27 \%$; v, 1 eq. $\mathrm{PhCH}=\mathrm{PPh}_{3}, 35 \%$.

Scheme 3. Synthetic routes to $\beta, \gamma$-dioxo-stabilised ylide 14

The stable crystalline ylide $\mathbf{1 4}$ was now subjected to FVP using a conventional flow system at a pressure of $10^{-2}$ Torr and temperatures in the range $700-850{ }^{\circ} \mathrm{C}$. In agreement with our earlier studies, ${ }^{6}$ pyrolysis at the lowest temperature gave only $\mathrm{Ph}_{3} \mathrm{PO}$ and the alkynyl ketone 15 with the methoxy group still intact (Scheme 4). The latter was readily separated by chromatography on silica and identified by comparison of 
its ${ }^{1} \mathrm{H}$ and ${ }^{13} \mathrm{C}$ NMR data with published values, ${ }^{19,20}$ By increasing the temperature in the FVP of ylide 14, or re-pyrolysing alkynyl ketone $\mathbf{1 5}$ obtained as above, heterocyclic products were obtained but, surprisingly, the expected flavone (16) was accompanied by 2-phenylbenzofuran (17), readily identified by comparison of its spectroscopic data with that obtained in our earlier studies. ${ }^{6}$<smiles>COc1ccccc1C(=O)C(=O)C(=P)c1ccccc1</smiles>

14

16<smiles></smiles>

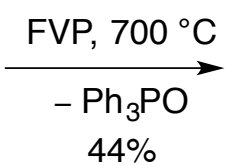

$44 \%$

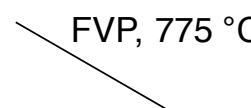<smiles>COc1ccccc1C(=O)C#Cc1ccccc1</smiles>

15

FVP, $775^{\circ} \mathrm{C}$<smiles>O=c1cc(-c2ccccc2)oc2ccccc12</smiles><smiles>CCCCC(=P)CCC</smiles>

17

Scheme 4. Pyrolysis of $\beta, \gamma$-dioxo-stabilised ylide 14

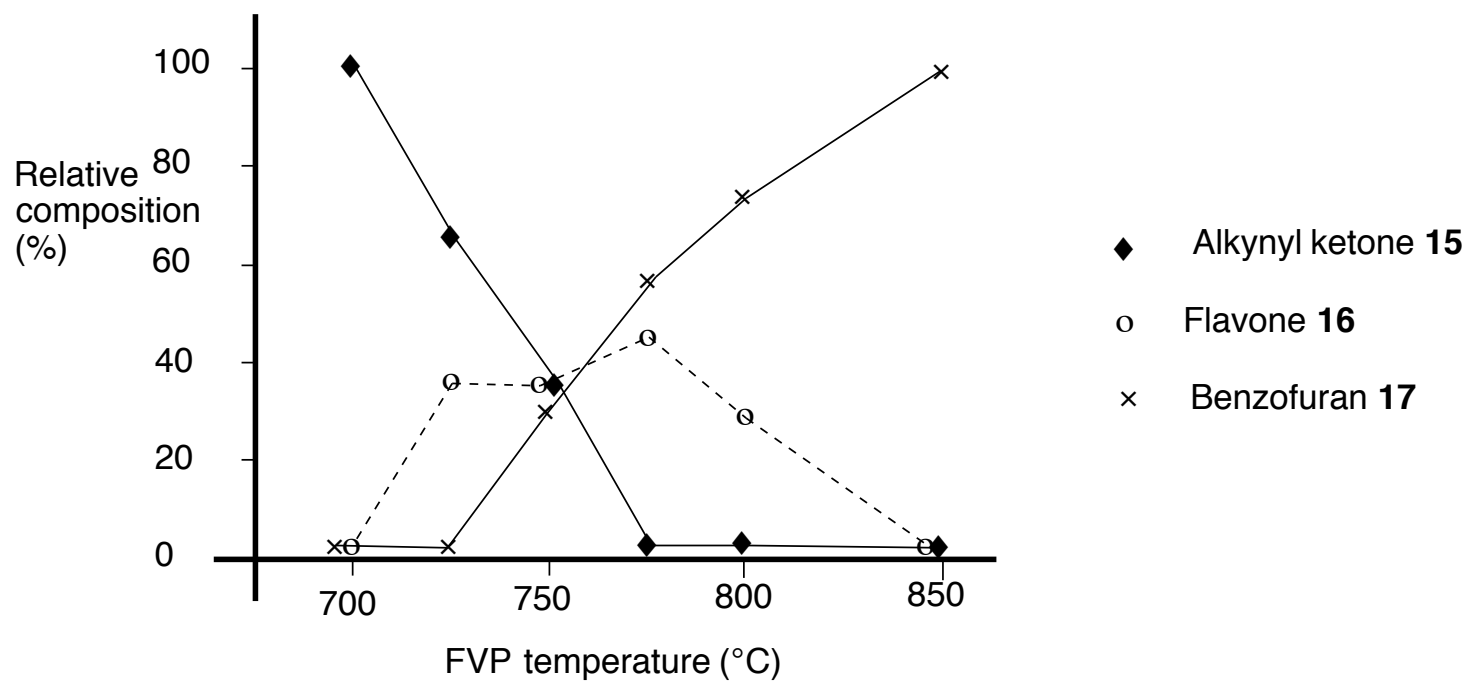

Figure 1. Products from FVP of $\mathbf{1 4}$ or $\mathbf{1 5}$ as a function of temperature 
The product-temperature profile (Figure 1) seemed to suggest that flavone was acting as an intermediate on the way to 17 , which was the sole product at $850{ }^{\circ} \mathrm{C}$. However we are not aware of any previous report of such thermal decarbonylation of flavones to arylbenzofurans, and indeed flavone prepared by an authentic route ${ }^{21}$ was recovered unchanged from FVP over the whole range $700-850{ }^{\circ} \mathrm{C}$. Similar mixtures of 16 and 17 could however be produced by FVP of 3 -iodoflavone (18) ${ }^{22}$ in this temperature range. This points to decarbonylation at the stage of the radical 20, formed either by loss of $\mathrm{Me} \cdot$ from 15 and 6-endo-dig cyclisation of the resulting intermediate 19 or by loss of $\mathrm{I}^{\bullet}$ from 18 (Scheme 5). Interestingly there was no trace of the isomeric aurone product, which would result from 5-exo-dig cyclisation of 19.

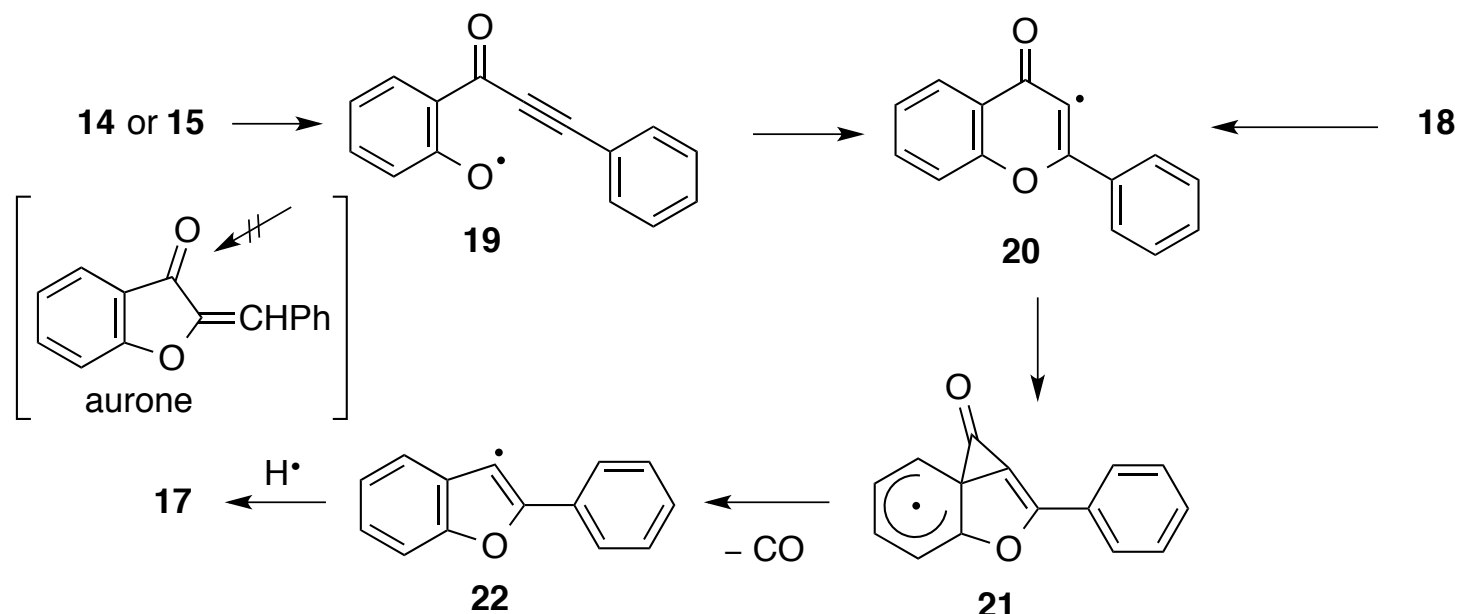

Scheme 5. Proposed mechanism for the formation of 2-phenylbenzofuran

In an attempt to prevent the undesired decarbonylation we considered protecting the carbonyl group being lost as the thermally robust 1,3-dioxolane. The desired ylides, analogous to 9 but with the carbonyl adjacent to the methoxy-bearing benzene ring in the form of the ketal, would be most easily accessed by deprotonation and acylation of the phosphonium salt 27 but, despite extensive efforts (Scheme 6), we were unable to obtain this. The previously unknown dioxolane ester $\mathbf{2 3}$ was readily prepared by ketalisation of $\mathbf{1 0}$ and was reduced in good yield to the alcohol 24. All attempts to brominate this failed and, even when the dersired bromide $\mathbf{2 6}$ was obtained by ketalisation of the $\alpha$-bromo ketone $\mathbf{2 5}$, it could not be converted into the phosphonium salt $\mathbf{2 7}$ even under forcing conditions. We attribute the failure of these reactions to the "neopentyl effect" in which an adjacent quaternary $\mathrm{sp}^{3}$ carbon centre renders $\mathrm{S}_{\mathrm{N}} 2$ reaction all but impossible. An attempt to install the dioxolane protection at the stage of the already formed phosphonium salt $\mathbf{2 8}$ was also unsuccessful, likely due to the sterically hindered nature of its carbonyl group. 


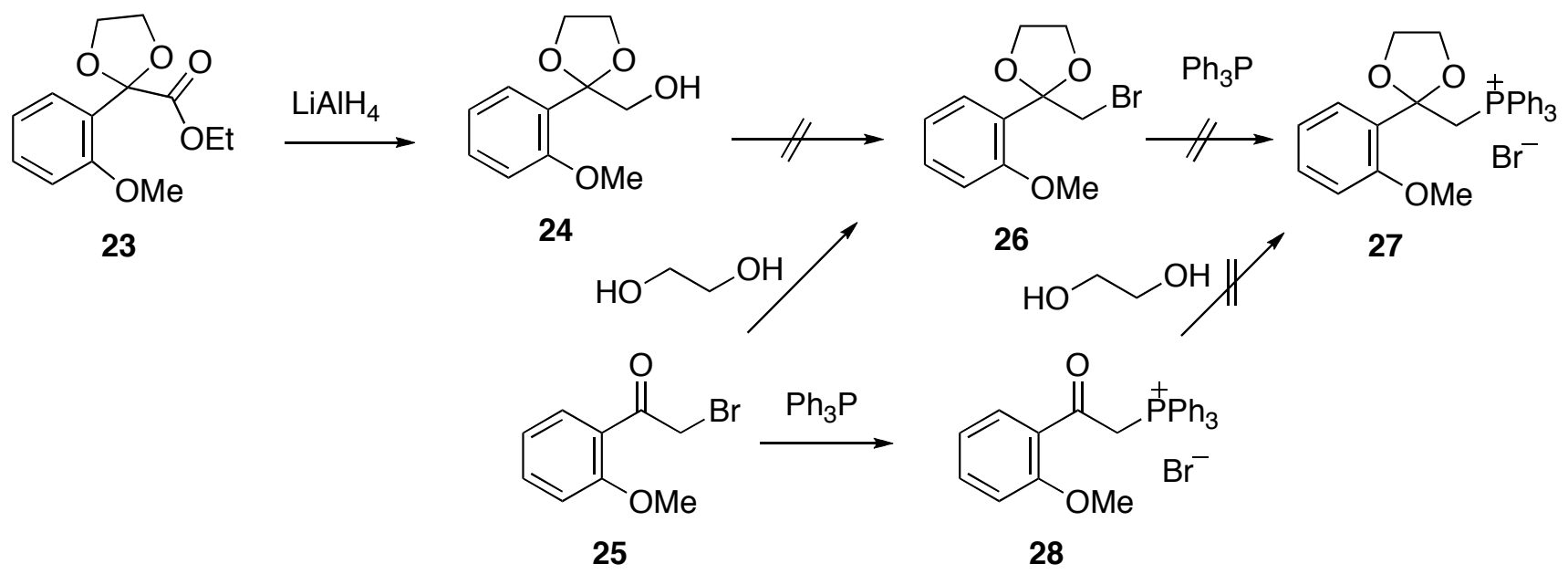

Scheme 6. Approaches to protected phosphonium salt 27

Despite the previously mentioned problem of competing elimination of $\mathrm{Ph}_{3} \mathrm{PO}$ in two directions, together with the new complicating factor of possible decarbonylation as discovered in the FVP of $\mathbf{1 4}$, we decided to examine one example of the alternative precursor ylide type corresponding to 9 . In order to increase the chance of a clear and positive pyrolysis result, we made two structural modifications: the first was to install a marker group (Me) that would give a singlet ${ }^{1} \mathrm{H}$ NMR signal for each possible cyclisation product, and the second was to replace the benzoyl group at the opposite end of the molecule from the methoxyphenyl by cinnamoyl. The thinking behind this second change was to intercept the intermediate benzopyranon-3-yl radical in an intramolecular $S_{H} A r$ cyclisation to give a tetracyclic product before it could undergo decarbonylation. This strategy was previously successful in allowing us to obtain ring-fused carbazoles from cinnamoyl ylides where simpler benzoyl ylides took a different route to afford quinolines. ${ }^{10}$ Synthesis of the target ylide 34 (Scheme 7) starts with Fries rearrangement of $p$-tolyl acetate

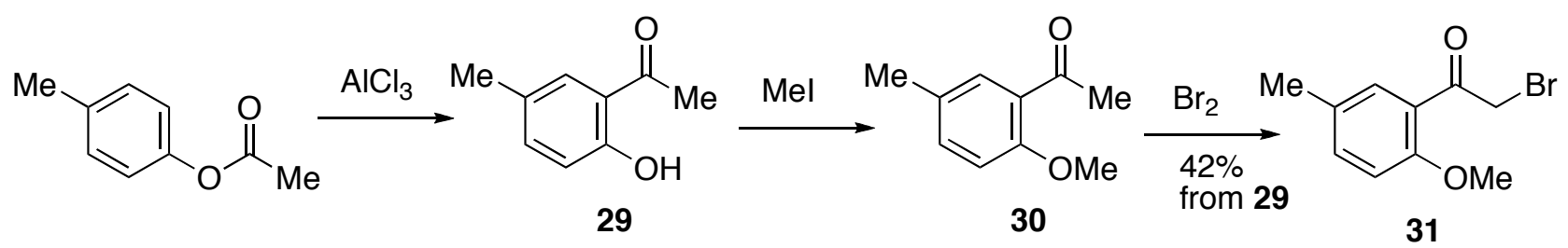<smiles>COc1ccc(C)cc1C(=O)Cc1ccccc1</smiles>

Scheme 7. Synthetic route to $\beta, \beta$ '-dioxo ylide 34 suitable to form tetracyclic domino cyclisation products 
to give the hydroxyacetophenone $\mathbf{2 9}$ which was methylated and brominated to give $\mathbf{3 1}$ as shown. Reaction with triphenylphosphine followed by aqueous sodium carbonate gave the new stabilised ylide $\mathbf{3 3}$ in good yield, which was finally treated with cinnamoyl chloride and triethylamine to afford the target ylide 34 .

When this ylide was now subjected to FVP there was complete reaction at $750{ }^{\circ} \mathrm{C}$ with loss of $\mathrm{Ph}_{3} \mathrm{PO}$ and OMe to give, after chromatographic separation, a mixture of just three ring-methyl containing heterocyclic products each present in about $20 \%$ yield as judged by the ${ }^{1} \mathrm{H}$ NMR signals around $\delta 2.5$ (Scheme 8). Unfortunately due to their extremely similar properties we were unable to separate these chromatographically despite extensive efforts. Although none of the compounds are previously known, a distinctive ${ }^{1} \mathrm{H}$ NMR signal at $\delta 10.2(\mathrm{dd}, J=5.4,0.6 \mathrm{~Hz}$ ) could be confidently assigned to the "bay region" $1-\mathrm{H}$ of 10-methyl-12H-benzo[a]xanthen-12-one (35) which is deshielded through space by the proximate $\mathrm{C}=\mathrm{O}$. Further signals in the range 8.4-8.75 were consistent with the isomeric benzonaphthofuran isomers $\mathbf{3 6}$ and $\mathbf{3 7}$ and their overall spectra were highly consistent with the analogues lacking the ring-methyl which we previously obtained from FVP of 2-methoxybenzylidene(cinnamoyl)triphenylphosphorane (i.e. compound 1 with $\mathrm{XR}=\mathrm{OMe}$ and $\mathrm{Y}=-$ $\mathrm{CH}=\mathrm{CH}-\mathrm{Ph}){ }^{7}$ The formation of 35 clearly points to the "correct" direction of $\mathrm{Ph}_{3} \mathrm{PO}$ elimination and subsequent domino reaction as desired, while $\mathbf{3 6}$ is the product expected if the benzopyran-3-yl radical intermediate on the way to $\mathbf{3 5}$ undergoes the same decarbonylation as observed for the close analogue $\mathbf{2 0}$ and then cylises directly. The isomer $\mathbf{3 7}$ is likely formed via reversible intramolecular addition of the benzofuryl radical to the styryl double bond and re-opening of the resulting cyclopropenylmethyl radical in the other sense as also observed in our previous work (Scheme 9). ${ }^{7}$ No products derived from the alternative elimination of $\mathrm{Ph}_{3} \mathrm{PO}$ adjacent to the methoxy-bearing ring were identified although we cannot rigorously exclude their presence in the rather complex initial product mixture. Overall this result has confirmed the selectivity problems inherent in the approach: although the desired initial intermediate is being formed, it has too many competing thermal pathways open to it to give a preparatively useful method.

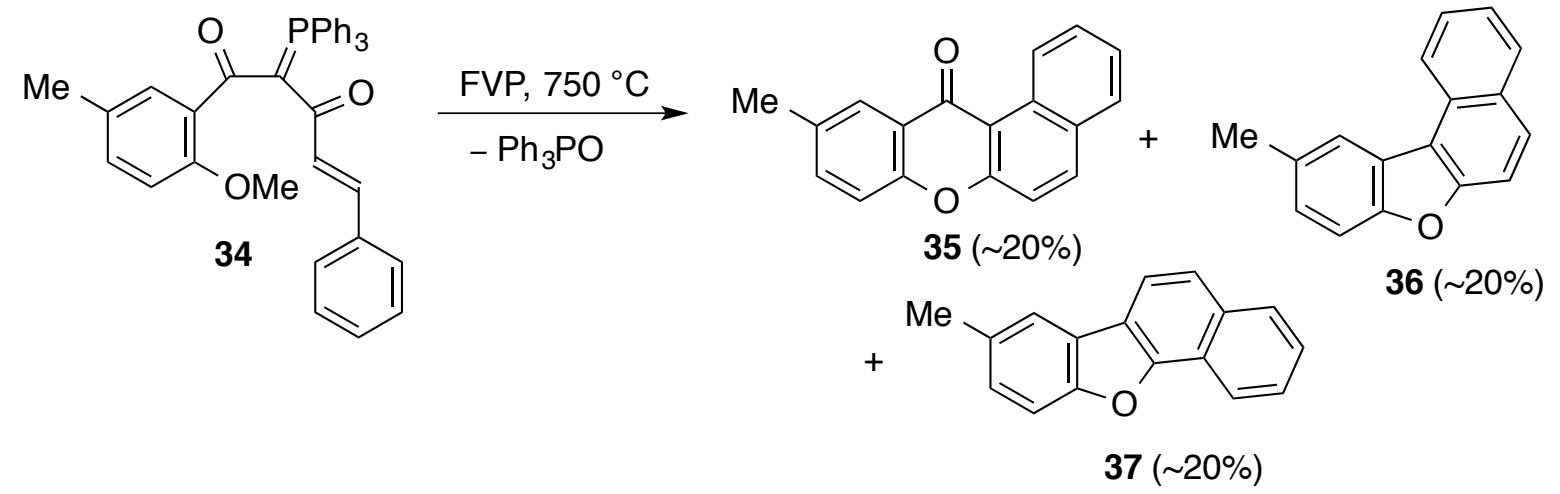

Scheme 8. Result of FVP of the ylide 34 


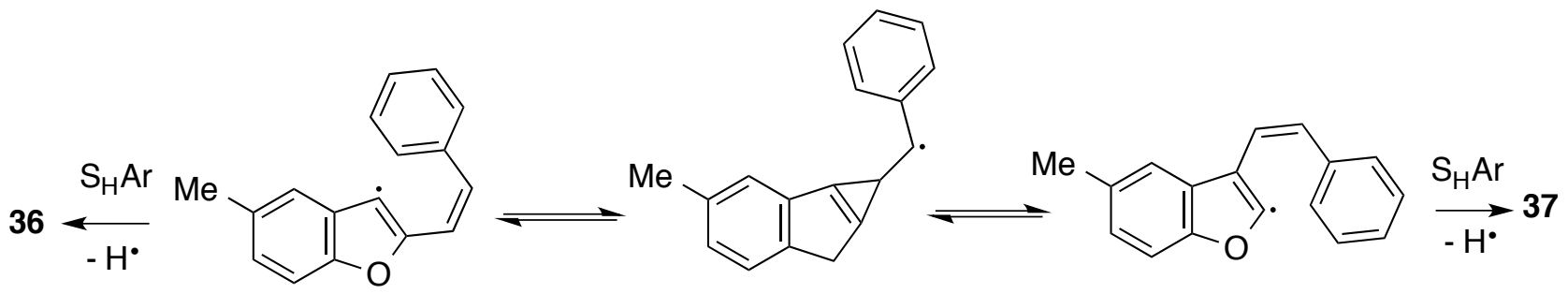

Scheme 9. Proposed mechanism for formation of isomers $\mathbf{3 6}$ and 37

One way of directing the phosphine oxide elimination to the desired direction would be to replace one $\mathrm{C}=\mathrm{O}$ by $\mathrm{C}=\mathrm{S}$. Most simple $\beta$-thioxo ylides do eliminate $\mathrm{Ph}_{3} \mathrm{PS}$ readily under FVP conditions, ${ }^{23}$ and we have obtained kinetic evidence that elimination of $\mathrm{Ph}_{3} \mathrm{PS}$ is 40-65 times faster than $\mathrm{Ph}_{3} \mathrm{PO}$ for comparable ylides. ${ }^{24}$ However to our knowledge there is no published case of competitive thermal elimination of $\mathrm{Ph}_{3} \mathrm{PS}$ vs. $\mathrm{Ph}_{3} \mathrm{PO}$ within a single oxo/thioxo ylide. Several approaches to the simple case of $\mathrm{PhC}(=\mathrm{S})-$ $\mathrm{C}\left(=\mathrm{PPh}_{3}\right)-\mathrm{C}(=\mathrm{O}) \mathrm{Ph}$ failed but we were able to obtain the dioxo/thioxo ylide $\mathbf{4 0}$ using the method of Tebby and coworkers (Scheme 10), ${ }^{25}$ involving addition of $\mathrm{Ph}_{3} \mathrm{P}$ and sulfur to dibenzoylacetylene (39), itself conveniently obtained by FVP of the trioxo ylide $38 .{ }^{26}$ When this was subjected to FVP there was complete reaction at 700 or $750{ }^{\circ} \mathrm{C}$ but ${ }^{31} \mathrm{P}$ NMR showed almost no selectivity with a ratio of $\mathrm{Ph}_{3} \mathrm{PS}$ to $\mathrm{Ph}_{3} \mathrm{PO}$ of 1.2 to 1 in each case. This is doubly surprising since not only was $\mathrm{Ph}_{3} \mathrm{PS}$ expected to be eliminated much more readily than $\mathrm{Ph}_{3} \mathrm{PO}$, but it is in stark contrast to the complete selectivity towards elimination of $\mathrm{Ph}_{3} \mathrm{PO}$ across the central position of most trioxo ylides as seen for $\mathbf{3 8}$ in Scheme $9{ }^{26}$

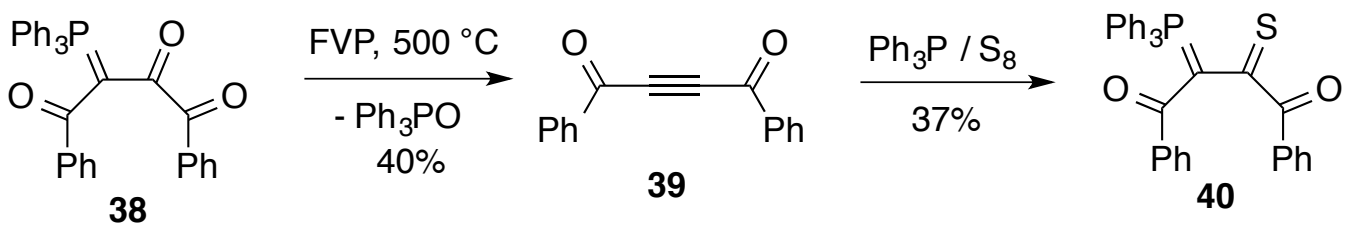

Scheme 10. Synthesis of $\beta^{\prime}, \gamma$-dioxo- $\beta$-thioxo ylide $\mathbf{4 0}$

In the light of the results already described, the $\mathrm{N}$-phenylimidoyl function seemed likely to have the desired properties, being an easily introduced and removed protection for $\mathrm{C}=\mathrm{O}$ which was unlikely to eliminate $\mathrm{Ph}_{3} \mathrm{P}=\mathrm{NPh}$ rather than $\mathrm{Ph}_{3} \mathrm{PO}$. Very few imidoyl and carbonyl-substituted ylides are known but a recent example is $\mathrm{MeO}_{2} \mathrm{C}-\mathrm{C}\left(=\mathrm{PPh}_{3}\right)-\mathrm{C}(=\mathrm{NPh})-\mathrm{CO}_{2} \mathrm{Me}$ formed by addition of $\mathrm{Ph}_{3} \mathrm{P}=\mathrm{NPh}$ to dimethyl acetylenedicarboxylate ${ }^{27}$ in direct analogy to the formation of $\mathbf{4 0}$ from $\mathbf{3 9}$. The benzopyranone precusor ylide 44, with a cinnamoyl group to allow a second domino cyclisation step, was therefore designed and synthesised (Scheme 11). Treatment of 2-methoxybenzanilide 41, readily obtained from the acid chloride and aniline, with phosphorus pentachloride gave the unstable imidoyl chloride $\mathbf{4 2}$ in low yield after 
distillation. This was used immediately to acylate methylenetriphenylphosphorane affording the crystalline imidoyl-stabilised ylide $\mathbf{4 3}$. When this was treated with cinnamoyl chloride and triethylamine it gave the target ylide 44. FVP of this gave complete loss of $\mathrm{Ph}_{3} \mathrm{PO}$ at $750{ }^{\circ} \mathrm{C}$ to produce the desired benzopyranone $\mathrm{N}$-phenylimine $\mathbf{4 5}$ in which, interestingly, the second planned cyclisation has not taken place. In view of the strong through-space interaction of $\mathrm{H}-1$ with the carbonyl in $\mathbf{3 5}$, it is clear that the analogous tetracyclic $N$-phenylimine expected from the additional cyclisation of $\mathbf{4 5}$ would be extremely hindered especially in one of the two geometrical isomers and this probably explains the failure of the second cyclisation. Further domino cyclisation approaches to benzopyranone and flavone systems using $N$-phenylimidoyl ylides are now being examined.<smiles>COc1ccccc1C(C)=O</smiles><smiles>NP[13CH2]P</smiles><smiles>COc1ccccc1C(=O)Nc1ccccc1</smiles>

41<smiles>COc1ccccc1/C(Cl)=N/c1ccccc1</smiles>

42

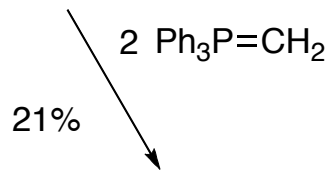

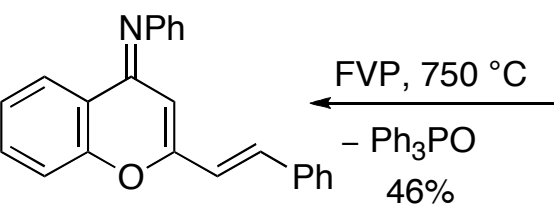

45<smiles>COc1ccccc1/C(=N\c1ccccc1)C(=P)c1ccccc1</smiles>

44

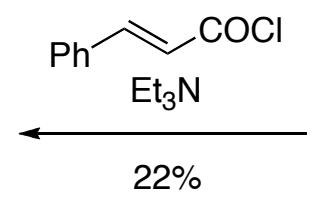<smiles>COc1ccccc1/C(C=[Pb])=N\c1ccccc1</smiles>

Scheme 11. Synthesis and FVP of $\beta$-oxo- $\beta$ '-phenylimino ylide 44

\section{EXPERIMENTAL}

Melting points were recorded on a Reichert hot-stage microscope and are uncorrected. IR spectra were determined on a Perkin-Elmer 1420 spectrometer as Nujol mulls or thin films. All NMR spectra were obtained using a Bruker Avance 300 or 400 spectrometers, at 300 or $400 \mathrm{MHz}$ for ${ }^{1} \mathrm{H}, 75$ or $100 \mathrm{MHz}$ for ${ }^{13} \mathrm{C}$, and 121 or $161 \mathrm{MHz}$ for ${ }^{31} \mathrm{P}$, and are reported in ppm to high frequency of TMS as internal standard for $\mathrm{H}$ and $\mathrm{C}$ and relative to external $85 \% \mathrm{H}_{3} \mathrm{PO}_{4}$ for $\mathrm{P}$. All spectra were recorded in $\mathrm{CDCl}_{3}$. Mass spectra were recorded using a Micromass GCT spectrometer using CI or ESI.

For flash vacuum pyrolysis (FVP), the sample was volatilised from a tube in a Büchi Kugelrohr oven through a $30 \times 2.5 \mathrm{~cm}$ horizontal fused quartz tube. This was heated externally by a Carbolite Eurotherm tube furnace MTF-12/38A, the temperature being monitored by a Pt/Pt-13\% Rh thermocouple situated at the centre of the furnace. The products were collected in a U-shaped trap cooled in liquid nitrogen. The whole system was maintained at a pressure of $10^{-2}$ Torr by an Edwards Model E2M5 high capacity rotary 
oil pump, the pressure being measured by a Pirani gauge situated between the cold trap and the pump. Under these conditions the contact time in the hot zone was estimated to be $10 \mathrm{~ms}$.

\section{Starting Materials}

Benzyltriphenylphosphonium chloride was prepared by heating a solution of triphenylphosphine $(50.0 \mathrm{~g}$, $190 \mathrm{mmol})$ and benzyl chloride $(26.2 \mathrm{~g}, 210 \mathrm{mmol})$ in toluene $\left(500 \mathrm{~cm}^{3}\right)$ under reflux for $24 \mathrm{~h}$. The white precipitate was filtered off and washed with diethyl ether to give the product $(50.53 \mathrm{~g}, 69 \%)$ as a colourless crystalline solid, mp 328-330 ${ }^{\circ} \mathrm{C}$ (lit., ${ }^{28} 325-328{ }^{\circ} \mathrm{C}$ ); ${ }^{1} \mathrm{H}$ NMR $\delta$ 7.8-7.7 (m, 9H), 7.65-7.55 $(\mathrm{m}, 6 \mathrm{H}), 7.25-7.15(\mathrm{~m}, 1 \mathrm{H}), 7.15-7.10(\mathrm{~m}, 4 \mathrm{H}), 5.52\left(\mathrm{~d}, J=14.4 \mathrm{~Hz}, 2 \mathrm{H}, \mathrm{CH}_{2}\right) ;{ }^{31} \mathrm{P} \mathrm{NMR} \delta+24.6$.

Dibenzoylacetylene 39 was prepared by FVP of the ylide 38 at $500{ }^{\circ} \mathrm{C}(40 \%) .{ }^{26}$

\section{Preparation of ethyl 2-(2-methoxyphenyl)-2-oxoacetate 10}

A solution of 2-bromoanisole $(27.0 \mathrm{~g}, 144 \mathrm{mmol})$ in diethyl ether $(270 \mathrm{~mL})$ was cooled to $-70{ }^{\circ} \mathrm{C}$, and butyllithium in hexane $(57.6 \mathrm{~mL}, 2.5 \mathrm{M}, 144 \mathrm{mmol})$ was added by syringe, and stirred for 45 mins. Diethyl oxalate $(78 \mathrm{~mL}, 84.0 \mathrm{~g}, 576 \mathrm{mmol})$ was added rapidly with stirring and allowing the mixture to warm up to RT. After $1 \mathrm{~h}$, saturated $\mathrm{NH}_{4} \mathrm{Cl}$ solution was added, the organic layer was separated and the aqueous phase was extracted with diethyl ether. The combined organic phase was dried over $\mathrm{MgSO}_{4}$ and evaporated and the residue distilled by Kugelrohr $\left(170{ }^{\circ} \mathrm{C}, 0.5 \mathrm{mmHg}\right)$ to give the product $(17.96 \mathrm{~g}, 60 \%)$ as a deep yellow liquid; ${ }^{1} \mathrm{H}$ NMR $\delta 7.88(\mathrm{dd}, J=7.8,1.8 \mathrm{~Hz}, 1 \mathrm{H}, \mathrm{H}-6), 7.59$ (ddd, $J=8.7,7.2,1.8 \mathrm{~Hz}, 1 \mathrm{H}$, H-4), 7.07 (ddd, $J=7.8,7.2,0.9 \mathrm{~Hz}, 1 \mathrm{H}, \mathrm{H}-5), 6.99$ (dd, $J=8.7,0.9 \mathrm{~Hz}, 1 \mathrm{H}, \mathrm{H}-3$ ), 4.39 (q, $J=7.2 \mathrm{~Hz}$, $2 \mathrm{H}, \mathrm{CH}_{2}$ ), $3.87(\mathrm{~s}, 3 \mathrm{H}, \mathrm{OMe}), 1.39(\mathrm{t}, J=7.2 \mathrm{~Hz}, 3 \mathrm{H}) ;{ }^{13} \mathrm{C}$ NMR $\delta 186.5$ (4ry, CO-Ar), 165.2 (4ry, CO-OEt), 160.2 (4ry, C-2), 136.3 (C-4), 130.6 (C-6), 122.6 (4ry, C-1), 121.2 (C-5), 111.9 (C-3), $61.7\left(\mathrm{CH}_{2}\right), 55.9(\mathrm{OMe}), 14.0\left(\mathrm{CH}_{3}\right)$. NMR spectra in agreement with lit. ${ }^{15}$

\section{Preparation of 2-(2-methoxyphenyl)-2-oxoacetic acid 11}

A solution of the ester $10(17.0 \mathrm{~g}, 81.7 \mathrm{mmol})$ and $\mathrm{NaOH}(12 \mathrm{~g}, 300 \mathrm{mmol})$ in water $(200 \mathrm{~mL})$ was heating on a steam bath for $1.5 \mathrm{~h}$. Then the solution was washed with diethyl ether, which was discarded, and acidified with dilute $\mathrm{HCl}$ leading to precipitation of a yellow oil. The mixture was extracted with diethyl ether again, and the combined ether extracts were dried with $\mathrm{MgSO}_{4}$ and evaporated to give the product $(9.5 \mathrm{~g}, 65 \%)$ as deep yellow crystals; mp 96-100 ${ }^{\circ} \mathrm{C}$ (lit., $\left.{ }^{16} 102-103{ }^{\circ} \mathrm{C}\right) ;{ }^{1} \mathrm{H}$ NMR $\delta 10.49$ (br s, $1 \mathrm{H}, \mathrm{OH}), 7.89$ (dd, $J=7.8,1.8 \mathrm{~Hz}, 1 \mathrm{H}, \mathrm{H}-6), 7.62$ (ddd, $J=8.7,8.4,1.8 \mathrm{~Hz}, 1 \mathrm{H}, \mathrm{H}-4), 7.07$ (ddd, $J=8.4$, 7.8, $0.9 \mathrm{~Hz}, 1 \mathrm{H}, \mathrm{H}-5), 7.02(\mathrm{dd}, J=8.7,0.9 \mathrm{~Hz}, 1 \mathrm{H}, \mathrm{H}-3), 3.90$ (s, 3H, OMe); ${ }^{13} \mathrm{C}$ NMR $\delta 185.7$ (4ry, CO-Ar), 169.3 (4ry, CO-OH), 160.5 (4ry, C-2), 136.8 (C-4), 130.7 (C-6), 122.0 (4ry, C-1), 121.4 (C-5), $112.2(\mathrm{C}-3), 56.0(\mathrm{OMe})$. NMR spectra in agreement with lit. $^{29}$ 
To a solution of 11 ( $2 \mathrm{~g}, 11 \mathrm{mmol})$ in $\mathrm{CH}_{2} \mathrm{Cl}_{2}$ was added oxalyl chloride $(1.65 \mathrm{~g}, 13 \mathrm{mmol})$ at $\mathrm{rt}$ followed by addition of a drop of DMF as catalyst. The mixture was stirred at this temperature until all evolution of gases ceased. All the volatiles were removed under vacuum to give the product $(2.04 \mathrm{~g}, 94 \%)$ as a brown liquid; ${ }^{1} \mathrm{H}$ NMR $\delta 7.92$ (dd, $\left.J=7.8,1.8 \mathrm{~Hz}, 1 \mathrm{H}, \mathrm{H}-6\right), 7.67$ (ddd, $\left.J=9.0,7.2,1.8 \mathrm{~Hz}, 1 \mathrm{H}, \mathrm{H}-4\right), 7.12$ (ddd, $J=7.8,7.2,0.9 \mathrm{~Hz}, 1 \mathrm{H}, \mathrm{H}-5), 7.04(\mathrm{dd}, J=9.0,0.9 \mathrm{~Hz}, 1 \mathrm{H}, \mathrm{H}-3), 3.92(\mathrm{~s}, 3 \mathrm{H}, \mathrm{OMe}) ;{ }^{13} \mathrm{C}$ NMR $\delta 181.2$ (4ry, COAr), 165.6 (4ry, COCl), 160.4 (4ry, C-2), 137.7 (C-4), 131.3 (C-6), 121.8 (C-5), 119.7 (4ry, C-1), 112.2 (C-3), 56.0 (OMe).

\section{Preparation of 1-(1H-benzo[d][1,2,3]triazol-1-yl)-2-(2-methoxyphenyl)ethane-1,2-dione 13}

To a solution of $1 \mathrm{H}$-1,2,3-benzotriazole $(11.90 \mathrm{~g}, 100 \mathrm{mmol})$ in $\mathrm{CH}_{2} \mathrm{Cl}_{2}$ (125 mL), thionyl chloride (2.97 $\mathrm{g}, 1.9 \mathrm{~mL}, 25 \mathrm{mmol}$ ) was added dropwise. The mixture was stirred at $\mathrm{rt}$ for $0.5 \mathrm{~h}$, and the acid $\mathbf{1 1}(4.5 \mathrm{~g}$, $25 \mathrm{mmol}$ ) was added. The mixture was stirred for a further $3 \mathrm{~h}$ at $\mathrm{rt}$ and the solid was filtered off and washed with $\mathrm{CH}_{2} \mathrm{Cl}_{2}$. Then the filtrate was washed with $2 \mathrm{M}$ aqueous $\mathrm{NaOH}$, water and brine. Drying and evaporation followed by recrystallisation of the residue from hexane and ethyl acetate gave the product $(0.75 \mathrm{~g}, 11 \%)$ as a yellow solid; $\mathrm{mp} 145-146{ }^{\circ} \mathrm{C}$; IR $1744,1669,1598,1482,1251,1017,750 \mathrm{~cm}^{-1} ;{ }^{1} \mathrm{H}$ NMR $\delta 8.37(\mathrm{dt}, J=8.4,1.0 \mathrm{~Hz}, 1 \mathrm{H}), 8.20-8.17(\mathrm{~m}, 2 \mathrm{H}), 7.75(\mathrm{ddd}, J=8.1,7.2,0.9 \mathrm{~Hz}, 1 \mathrm{H}), 7.69-7.57$ $(\mathrm{m}, 2 \mathrm{H}), 7.19(\mathrm{ddd}, J=8.0,7.0,0.9 \mathrm{~Hz}, 1 \mathrm{H}, \mathrm{H}-5$ of Ar-OMe), 6.93 (dd, $J=7.8,0.9 \mathrm{~Hz}, 1 \mathrm{H}, \mathrm{H}-3$ of Ar-OMe), 3.46 (s, 3H, OMe); ${ }^{13} \mathrm{C}$ NMR $\delta 185.1$ (4ry, COAr), 164.8 (4ry, CO-N), 160.5 (4ry, C-2 of ArOMe), 145.8 (4ry), 137.5 (C-4 of ArOMe), $130.8(\mathrm{CH}), 130.7(\mathrm{CH}), 130.7$ (4ry), 126.7 (C-6 of ArOMe), 122.1 (4ry, C-1 of ArOMe), 121.8 (C-5 of ArOMe), 120.4 (CH), 113.7 (CH), 112.3 (C-3 of ArOMe), 56.1 (OMe); HRMS (CI): Calcd for $\mathrm{C}_{15} \mathrm{H}_{12} \mathrm{NO}_{3}\left(\mathrm{M}^{+}-\mathrm{N}_{2}\right)$ : 254.0817. Found: 254.0825 .

Preparation of 1-(2-methoxyphenyl)-3-phenyl-3-(triphenylphosphoranylidene)propane-1,2-dione 14 A solution of benzyltriphenylphosphonium chloride $(3.9 \mathrm{~g}, 10 \mathrm{mmol})$ in dry THF $(30 \mathrm{~mL})$ was stirred under nitrogen, while a solution of BuLi in hexanes $(4.0 \mathrm{~mL}, 2.5 \mathrm{M}, 10 \mathrm{mmol})$ was added. The resulting solution was stirred for a further $2 \mathrm{~h}$, before adding acid chloride $12(1.0 \mathrm{~g}, 5 \mathrm{mmol})$ in dry THF (10 mL). After stirring for another $18 \mathrm{~h}$, the mixture was added to water and extracted with diethyl ether. The combined solution was dried over $\mathrm{MgSO}_{4}$ and evaporated to give the product $(1.37 \mathrm{~g}, 27 \%)$ as a yellow crystalline solid; mp $233-235{ }^{\circ} \mathrm{C}$; IR $1743,1655,1594,1289,1259,962,757 \mathrm{~cm}^{-1}$; ${ }^{1} \mathrm{H}$ NMR $\delta 7.75-7.62$ $(\mathrm{m}, 7 \mathrm{H}), 7.55-7.47(\mathrm{~m}, 3 \mathrm{H}), 7.45-7.33(\mathrm{~m}, 7 \mathrm{H}), 7.05-6.95(\mathrm{~m}, 2 \mathrm{H}), 6.93-6.85(\mathrm{~m}, 5 \mathrm{H}), 3.89(\mathrm{~s}, 3 \mathrm{H}$, OMe); ${ }^{13} \mathrm{C}$ NMR $\delta 196.2$ (d, $J=15 \mathrm{~Hz}, 4 \mathrm{ry}, \mathrm{CO}-\mathrm{Ar}$ ), 184.8 (d, $\left.J=7 \mathrm{~Hz}, 4 \mathrm{ry}, C O-\mathrm{CP}\right), 158.7$ (4ry, C-2 of Ar), 135.7 (d, $J=10 \mathrm{~Hz}$, 4ry, C-1 of Ph), $136.1(\mathrm{CH}), 136.0(\mathrm{CH}), 134.2(\mathrm{~d}, J=10 \mathrm{~Hz}, 6 \mathrm{CH}, \mathrm{C}-2$ of $\mathrm{PPh}_{3}$ ), $133.3(\mathrm{CH}), 131.9$ (d, $\left.J=3 \mathrm{~Hz}, 3 \mathrm{CH}, \mathrm{C}-4 \mathrm{of} \mathrm{PPh}_{3}\right), 131.6(\mathrm{CH}), 128.5(\mathrm{~d}, J=12 \mathrm{~Hz}, 6 \mathrm{CH}, \mathrm{C}-3$ of $\mathrm{PPh}_{3}$ ), 127.3 (d, $\left.J=2 \mathrm{~Hz}, 2 \mathrm{CH}\right), 126.8$ (d, $J=3 \mathrm{~Hz}, 4 \mathrm{ry}, \mathrm{C}-1$ of Ar), 125.7 (d, $J=90 \mathrm{~Hz}, 4 \mathrm{ry}, \mathrm{C}-1$ of $\left.\mathrm{PPh}_{3}\right), 125.0(\mathrm{~d}, J=2 \mathrm{~Hz}, \mathrm{CH}), 120.2(\mathrm{CH}), 111.2(\mathrm{CH}), 66.4\left(\mathrm{~d}, J=103 \mathrm{~Hz}, 4 \mathrm{ry}, \mathrm{C}=\mathrm{PPh}_{3}\right), 55.5(\mathrm{OMe})$; 
${ }^{31} \mathrm{P}$ NMR $\delta+17.02 ;$ MS $\left(\mathrm{ES}^{+}\right) \mathrm{m} / z 536.68\left(\mathrm{M}^{+}+\mathrm{Na}, 100 \%\right)$. HRMS (ESI) Calcd for $\mathrm{C}_{34} \mathrm{H}_{28} \mathrm{O}_{3} \mathrm{P}\left(\mathrm{M}^{+}+\mathrm{H}\right)$ : 515.1776. Found: 515.1777.

Alternative preparation of 1-(2-methoxyphenyl)-3-phenyl-3-(triphenylphosphoranylidene)propane1,2-dione 14

A solution of benzyltriphenylphosphonium chloride $(0.79 \mathrm{~g}, 2 \mathrm{mmol})$ in dry THF $(10 \mathrm{~mL})$ was stirred under $\mathrm{N}_{2}$, while a solution of BuLi in hexanes $(0.8 \mathrm{~mL}, 2.5 \mathrm{M}, 2 \mathrm{mmol})$ was added. The resulting solution was stirred for a further $2 \mathrm{~h}$, before adding $13(0.56 \mathrm{~g}, 2 \mathrm{mmol})$ in dry THF $(10 \mathrm{~mL})$. After stirring for another $24 \mathrm{~h}$, the mixture was added to water and extracted with diethyl ether. The combined solution was dried and evaporated to give the product $(0.35 \mathrm{~g}, 35 \%)$ as a yellow crystalline solid; mp $233-235{ }^{\circ} \mathrm{C}$; spectra identical to those quoted above.

\section{FVP of Ylide 14}

FVP of the title ylide $(55.2 \mathrm{mg})$ at $700{ }^{\circ} \mathrm{C}$ and $2-3 \times 10^{-2}$ Torr gave a yellow solid at the exit of the furnace. The mixture was separated by column chromatography with ether-hexane (1:9) as eluant to give 1-(2-Methoxyphenyl)-3-phenylprop-2-yn-1-one 15 (11.2 mg, 44\%) as yellow crystals; mp 98-100 ${ }^{\circ} \mathrm{C}$; ${ }^{1} \mathrm{H}$ NMR $\delta 8.10(\mathrm{dd}, J=7.8,1.8 \mathrm{~Hz}, 1 \mathrm{H}, \mathrm{ArH}), 7.66-7.63(\mathrm{~m}, 2 \mathrm{H}), 7.55(\mathrm{ddd}, J=9.0,7.2,1.8 \mathrm{~Hz}, 1 \mathrm{H}$, $\mathrm{ArH}), 7.49-7.37(\mathrm{~m}, 3 \mathrm{H}), 7.09-7.02(\mathrm{~m}, 2 \mathrm{H}), 3.98$ (s, 3H, OMe) [agreement with lit. ${ }^{19}$ ]; ${ }^{13} \mathrm{C}$ NMR $\delta$ 176.6 (4ry, CO), 159.8 (4ry, C-2 of Ar), $135.0(\mathrm{CH}), 132.9(\mathrm{CH}), 132.7(\mathrm{CH}), 130.4(\mathrm{CH}), 128.6(\mathrm{CH})$, 126.7 (4ry, C-1 of Ar), 120.7 (4ry, C-1 of Ph), $120.3(\mathrm{CH}), 112.2(\mathrm{CH}), 91.6$ (4ry, $C \equiv \mathrm{C}), 89.2$ (4ry, $\mathrm{C} \equiv C$ ), $55.9(\mathrm{OMe})$ [agreement with lit., ${ }^{20}$ ].

\section{FVP of 15}

FVP of the title compound $15(54.2 \mathrm{mg})$ at $775^{\circ} \mathrm{C}$ and $2-3 \times 10^{-2}$ Torr gave a yellow solid at the exit of the furnace. NMR results showed the crude product was a mixture of flavone $\mathbf{1 6}$ and 2-phenylbenzofuran 17:

flavone; ${ }^{1} \mathrm{H}$ NMR $\delta 6.84(\mathrm{~s}, 1 \mathrm{H}) ;{ }^{13} \mathrm{C}$ NMR identical to material prepared below.

2-phenylbenzofuran; ${ }^{1} \mathrm{H}$ NMR $\delta 7.02$ (d, $\left.J=0.9 \mathrm{~Hz}, 1 \mathrm{H}\right) ;{ }^{13} \mathrm{C}$ NMR $\delta 155.9,154.9,141.3,128.7$ (2C), $128.7,126.2,124.8$ (2C), 124.2, 122.9, 120.8, 111.1, 101.2 [agreement with lit., ${ }^{6}$ ].

For the relative composition of the product from FVP of $\mathbf{1 4}$ or $\mathbf{1 5}$ at different temperatures see Figure 1.

\section{Preparation of Flavone 16}

To a $50 \mathrm{~mL}$ conical flask were added in order with stirring, $o$-hydroxyacetophenone $(4.5 \mathrm{~g}, 4 \mathrm{~mL}, 0.03$ mol), benzoyl chloride $(7 \mathrm{~g}, 5.8 \mathrm{~mL}, 0.05 \mathrm{~mol})$ and pyridine $(7 \mathrm{~mL})$. After the heat of reaction had subsided, the mixture was poured into a well stirred mixture of $3 \% \mathrm{HCl}(200 \mathrm{~mL})$ and crushed ice $(70 \mathrm{~g})$. The resulting solid was filtered off, washed with methanol then water, and dried to give the 2-acetylphenyl benzoate $(4.62 \mathrm{~g}, 68 \%)$ as a pale yellow crystalline solid; mp $85-87^{\circ} \mathrm{C}\left(\right.$ lit.,$\left.{ }^{30} 87-88{ }^{\circ} \mathrm{C}\right)$. 
A solution of this ester $(4.5 \mathrm{~g}, 18 \mathrm{mmol})$ in pyridine $(17.1 \mathrm{~mL})$ was warmed to $50{ }^{\circ} \mathrm{C}$, and finely pulverised $\mathrm{KOH}(1.62 \mathrm{~g})$ was added to the hot solution. The mixture was stirred for $15 \mathrm{~min}$, then cooled to $\mathrm{rt}$ and acidified with aq. acetic acid $(10 \%, 22.5 \mathrm{~mL})$. The resulting precipitate was filtered off and dried to give 1-(2-hydroxyphenyl)-3-phenylpropane-1,3-dione (3.6 g, 83\%) as light brown crystals; mp 117$119^{\circ} \mathrm{C}$ (lit., $\left.{ }^{31} 118-120^{\circ} \mathrm{C}\right)$.

To a solution of the foregoing 1,3-dione (3.6 g, $0.015 \mathrm{~mol})$ in glacial acetic acid (20 mL) at room temperature, conc. sulfuric acid $(0.8 \mathrm{~mL})$ was added. The mixture was heated under reflux for $1 \mathrm{~h}$, with occasional shaking and then poured onto crushed ice (110 g) with vigorous stirring. After the ice had melted, the solid product was filtered off and washed with water until free from acid and dried to give the product 16 (3.14 g, 47\%) as yellow crystals; mp 97-99 ${ }^{\circ} \mathrm{C}$ (lit.,$\left.{ }^{32} 96-97{ }^{\circ} \mathrm{C}\right)$; ${ }^{1} \mathrm{H}$ NMR $\delta 8.24(\mathrm{dd}, J=8.1$, $1.8 \mathrm{~Hz}, 1 \mathrm{H}), 8.0-7.9(\mathrm{~m}, 2 \mathrm{H}), 7.71(\mathrm{~m}, 1 \mathrm{H}), 7.6-7.5(\mathrm{~m}, 4 \mathrm{H}), 7.43(\mathrm{~m}, 1 \mathrm{H}), 6.84(\mathrm{~s}, 1 \mathrm{H}) ;{ }^{13} \mathrm{C}$ NMR $\delta$ 178.4 (CO), 163.3 (4ry), 156.2 (4ry), $133.7(\mathrm{CH}), 131.7$ (4ry), $131.6(\mathrm{CH}), 129.0(2 \mathrm{CH}), 126.2(2 \mathrm{CH})$, $125.6(\mathrm{CH}), 125.1(\mathrm{CH}), 123.9(4 \mathrm{ry}), 118.0(\mathrm{CH}), 107.5(\mathrm{CH})$.

\section{Preparation of 3-iodoflavone 18}

A solution of lithium diisopropylamide was prepared by allowing butyllithium ( $4 \mathrm{~mL}, 2.5 \mathrm{M}, 10 \mathrm{mmol})$ to react with the diisopropylamine $(1.5 \mathrm{~mL}, 10 \mathrm{mmol})$ in $\mathrm{THF}(40 \mathrm{~mL})$ at $0{ }^{\circ} \mathrm{C}$ under $\mathrm{N}_{2}$. The solution was cooled to $-78{ }^{\circ} \mathrm{C}$ and stirred during the addition of $\mathbf{1 6}(2.22 \mathrm{~g}, 10 \mathrm{mmol})$. After $5 \mathrm{~min}$, a solution of iodine $(2.54 \mathrm{~g}, 10 \mathrm{mmol})$ in THF $(6 \mathrm{~mL})$ was added at $-78^{\circ} \mathrm{C}$ and the colour was observed to fade quickly. The mixture was added to water and extracted with ethyl acetate. The combined extracts were dried and evaporated to give the product $(2.92 \mathrm{~g}, 84 \%)$ as yellow crystals; mp $127-128{ }^{\circ} \mathrm{C}$ (lit. $\left.{ }^{22} 128{ }^{\circ} \mathrm{C}\right) ;{ }^{1} \mathrm{H}$ NMR $\delta 8.29(\mathrm{dd}, J=9,3 \mathrm{~Hz}, 1 \mathrm{H}), 7.8-7.69(\mathrm{~m}, 3 \mathrm{H}), 7.6-7.43(\mathrm{~m}, 5 \mathrm{H})$ [agreement with lit. ${ }^{22}$ ]; ${ }^{13} \mathrm{C}$ NMR $\delta$ 174.4 (CO), 164.4 (4ry), 155.7 (4ry), 134.9 (4ry), $134.1(\mathrm{CH}), 130.9(\mathrm{CH}), 129.3(2 \mathrm{CH}), 128.2(2 \mathrm{CH})$, $126.6(\mathrm{CH}), 125.7(\mathrm{CH}), 119.8(4 \mathrm{ry}), 117.5(\mathrm{CH}), 88.2(\mathrm{C}-\mathrm{I})$ [agreement with lit. ${ }^{33}$ ].

\section{FVP of Flavone}

FVP of the title compound $16(56.4 \mathrm{mg})$ at $850{ }^{\circ} \mathrm{C}$ and $2-3 \times 10^{-2}$ Torr gave a yellow solid at the exit of the furnace. NMR results showed the crude product was unchanged flavone.

\section{FVP of 3-iodoflavone}

FVP of the title compound $18(71.3 \mathrm{mg})$ at $750{ }^{\circ} \mathrm{C}$ and $2-3 \times 10^{-2}$ Torr gave a yellow solid at the exit of the furnace. NMR results showed the crude products were a mixture of flavone $\mathbf{1 6}$ and 2-phenylbenzofuran 17. The mixture was separated by column chromatography with ether-hexane (1:5) as eluant. As confirmed by NMR, the first fraction was the 2-phenylbenzofuran $(10.5 \mathrm{mg}, 26 \%)$ and the second fraction was flavone $(2.0 \mathrm{mg}, 4 \%)$.

Preparation of ethyl 2-(2-methoxyphenyl)-1,3-dioxolane-2-carboxylate 23 
The starting keto ester $\mathbf{1 0}(10.4 \mathrm{~g}, 50 \mathrm{mmol})$ was added to a stirred solution of ethylene glycol (12.8 g, $200 \mathrm{mmol})$ and $p$-toluenesulfonic acid $(285 \mathrm{mg}, 1.5 \mathrm{mmol})$ in toluene $(350 \mathrm{~mL})$, and the mixture was heated under reflux for $18 \mathrm{~h}$. After the mixture was cooled, it was washed with saturated aq. $\mathrm{NaHCO}_{3}$ and aq. $\mathrm{NaCl}$, and the organic phase was dried and evaporated to give the product, which was purified by kugelrohr distillation at 20 Torr and $170-175{ }^{\circ} \mathrm{C}$ to give a dark coloured liquid $(5.45 \mathrm{~g}, 46 \%) ;{ }^{1} \mathrm{H} \mathrm{NMR} \delta$ $7.63(\mathrm{dd}, J=7.5,1.8 \mathrm{~Hz}, 1 \mathrm{H}), 7.32(\mathrm{td}, J=7.5,1.8 \mathrm{~Hz}, 1 \mathrm{H}), 6.97(\mathrm{t}, J=7.0 \mathrm{~Hz}, 1 \mathrm{H}), 6.87(\mathrm{~d}, J=8.1 \mathrm{~Hz}$, $1 \mathrm{H}), 4.25(\mathrm{~m}, 2 \mathrm{H}), 4.19\left(\mathrm{q}, J=7 \mathrm{~Hz}, 2 \mathrm{H}, \mathrm{CH}_{2} \mathrm{CH}_{3}\right), 4.10(\mathrm{~m}, 2 \mathrm{H}), 3.78(\mathrm{~s}, 3 \mathrm{H}, \mathrm{OMe}), 1.19(\mathrm{t}, J=7 \mathrm{~Hz}$, $3 \mathrm{H}, \mathrm{CH}_{2} \mathrm{CH}_{3}$ ); ${ }^{13} \mathrm{C}$ NMR $\delta 169.0$ (4ry, C=O), 156.6 (4ry, C-2 of Ar), 130.2 (CH of Ar), 126.2 (4ry, O-C-O), 125.5 ( $\mathrm{CH}$ of $\mathrm{Ar}$ ), 120.2 ( $\mathrm{CH}$ of Ar), 110.7 ( $\mathrm{CH}$ of $\mathrm{Ar}$ ), 103.9 (4ry, C-1 of Ar), 65.9 (2C, $\left.\mathrm{OCH}_{2} \mathrm{CH}_{2} \mathrm{O}\right), 61.2\left(\mathrm{CH}_{2}-\mathrm{CH}_{3}\right), 55.4(\mathrm{OMe}), 13.8\left(\mathrm{CH}_{2}-\mathrm{CH}_{3}\right)$.

\section{Preparation of (2-(2-methoxyphenyl)-1,3-dioxolan-2-yl)methanol 24}

Under $\mathrm{N}_{2}$ atmosphere, the starting ester $23(7.20 \mathrm{~g}, 30.8 \mathrm{mmol})$ in dry THF (100 mL), was added dropwise to a stirred suspension of $\mathrm{LiAlH}_{4}(1.50 \mathrm{~g}, 39.5 \mathrm{mmol})$ in dry THF $(15 \mathrm{~mL})$ and the resulting mixture was heated under reflux for $4 \mathrm{~h}$. To destroy the excess of $\mathrm{LiAlH}_{4}$, water $(1.6 \mathrm{~mL})$ in THF $(10.5$ $\mathrm{mL})$ was carefully added to the mixture followed by $15 \%$ solution sodium hydroxide $(1.6 \mathrm{~mL})$ and finally water $(4.8 \mathrm{~mL})$. The mixture was stirred for $0.5 \mathrm{~h}$ and extracted with diethyl ether. The organic phase was washed with water, dried, and evaporated to give the crude product. This was recrystallised from hexane and ethyl acetate to give the product $(2.21 \mathrm{~g}, 34 \%)$ as colourless crystals; mp $120-123{ }^{\circ} \mathrm{C}$; IR $3484(\mathrm{OH})$, $1600,1584,1282,1242,1213,1077,1039,865,759 \mathrm{~cm}^{-1} ;{ }^{1} \mathrm{H}$ NMR $\delta 7.55(\mathrm{dd}, J=8.7,1.5 \mathrm{~Hz}, 1 \mathrm{H}, \mathrm{H}-6$ of Ar), 7.33 (ddd, $J=8.1,6.9,2.1 \mathrm{~Hz}, 1 \mathrm{H}, \mathrm{H}-4$ of Ar), 6.95 (m, 2H, H-3 and H-5 of Ar), 4.20-4.09 (m, 2H), 4.02-3.94 (m, 2H), 3.99 (s, 2H, CH $\left.\mathrm{H}_{2} \mathrm{OH}\right), 3.87$ (s, 3H, OMe), 2.07 (br s, $\left.1 \mathrm{H}, \mathrm{OH}\right),{ }^{13} \mathrm{C}$ NMR $\delta 157.3$ (4ry, C-2 of Ar), $130.1(\mathrm{CH}), 127.7(\mathrm{CH}), 126.8$ (4ry, C-2 of Ar), $120.3(\mathrm{CH}), 111.9(\mathrm{CH}), 109.3$ (4ry, OCO), $65.5\left(2 \mathrm{C}, \mathrm{CH}_{2} \mathrm{CH}_{2}\right), 65.4\left(\mathrm{CH}_{2} \mathrm{OH}\right), 55.8(\mathrm{OMe}) ; \mathrm{MS}\left(\mathrm{ES}^{+}\right) \mathrm{m} / z 233.02\left(\mathrm{M}^{+}+\mathrm{Na}, 100 \%\right)$; HRS: Calc for $\mathrm{C}_{11} \mathrm{H}_{14} \mathrm{O}_{4} \mathrm{Na}\left(\mathrm{M}^{+}+\mathrm{Na}\right): 233.0790$. Found: 233.0783 .

\section{Preparation of 2-bromo-1-(2-methoxyphenyl)ethanone 25}

To a stirred solution of 2-methoxyacetophenone $(10 \mathrm{~g}, 67 \mathrm{mmol})$ in diethyl ether $(100 \mathrm{~mL})$ was added dropwise bromine $(10.6 \mathrm{~g}, 3.4 \mathrm{~mL}, 67 \mathrm{mmol})$ while the temperature was kept below $30{ }^{\circ} \mathrm{C}$. The mixture was stirred at room temperature for $30 \mathrm{~min}$, and then was evaporated to dryness to give the product, which was purified by distillation at $170{ }^{\circ} \mathrm{C}$ to give the product $(4.77 \mathrm{~g}, 31 \%)$ as colourless crystals; mp 41-44 ${ }^{\circ} \mathrm{C}$ (lit., ${ }^{34} 40-44{ }^{\circ} \mathrm{C}$ ); ${ }^{1} \mathrm{H}$ NMR $\delta ~ 7.84-7.81$ (m, 1H, H-6), 7.55-7.49 (m, 1H, H-4), 7.06-6.98 (m, 2H, H-3 and 5), 4.61 (s, 2H, $\left.\mathrm{CH}_{2} \mathrm{Br}\right), 3.95$ (s, 3H, OMe).

\section{Preparation of 2-(bromomethyl)-2-(2-methoxyphenyl)-1,3-dioxolane 26}

This was prepared as for $\mathbf{2 3}$, using bromo ketone 25 (4.77 g, $20.83 \mathrm{mmol}$ ), ethylene glycol (1.94 g, 31.25 $\mathrm{mmol})$ and $p$-toluenesulfonic acid $(395 \mathrm{mg}, 2.08 \mathrm{mmol})$ in toluene $(210 \mathrm{~mL})$. The crude product was 
recrystallised from hexane/ethyl acetate to give the pure product $(3.47 \mathrm{~g}, 61 \%)$ as colourless crystals; $\mathrm{mp}$ 95-97 ${ }^{\circ} \mathrm{C}$; IR 1598, 1584, 1280, 1203, 1039, 761, $617 \mathrm{~cm}^{-1} ;{ }^{1} \mathrm{H}$ NMR $\delta$ 7.57-7.54 (m, 1H, H-6), 7.36$7.31(\mathrm{~m}, 1 \mathrm{H}, \mathrm{H}-4), 6.89-6.93\left(\mathrm{~m}, 2 \mathrm{H}, \mathrm{H}-3\right.$ and 5), 4.23-4.15 (m, 2H, $\left.\mathrm{C}_{2} \mathrm{H}_{4}\right), 4.02-3.95\left(\mathrm{~m}, 2 \mathrm{H}, \mathrm{C}_{2} \mathrm{H}_{4}\right)$, 3.98 (s, 2H, $\mathrm{CH}_{2} \mathrm{Br}$ ), 3.89 (s, 3H, OMe); ${ }^{13} \mathrm{C}$ NMR $\delta 157.1$ (4ry, C-2), 130.1 (C-4), 127.6 (C-6), 126.7 (4ry, C-1), 120.3 (C-5), 111.8 (C-3), 107.3 (4ry, OCO), 66.0 (2 C, $\left.\mathrm{C}_{2} \mathrm{H}_{4}\right), 55.9(\mathrm{OMe}), 37.0\left(\mathrm{CH}_{2} \mathrm{Br}\right)$; MS $\left(\mathrm{CI}^{+}\right) \mathrm{m} / z 273.01\left(\mathrm{M}^{+}+\mathrm{H}, 30 \%\right)$; HRMS (CI): Calc for $\mathrm{C}_{11} \mathrm{H}_{14} \mathrm{O}_{3}{ }^{79 / 81} \mathrm{Br}\left(\mathrm{M}^{+}+\mathrm{H}\right)$ : 273.0126/275.0106. Found: $273.0120 / 275.0100$.

\section{Preparation of (2-methoxybenzoylmethyl)triphenylphosphonium bromide 28}

The starting bromo ketone 25 (15.3 g, $67 \mathrm{mmol})$ and triphenylphosphine (17.6 g, $67 \mathrm{mmol}$ ) were stirred in toluene $(50 \mathrm{~mL})$ at room temperature overnight, then the precipitate was filtered off and dried to give the product $(18.41 \mathrm{~g}, 74 \%)$ as colourless crystals; mp $178-179{ }^{\circ} \mathrm{C}$; IR $1647,1595,1485,1439,1306$, 1049, 986, 746, $689 \mathrm{~cm}^{-1} ;{ }^{1} \mathrm{H}$ NMR $\delta 8.00-6.80(\mathrm{~m}, 19 \mathrm{H}), 6.08(\mathrm{~d}, J=11 \mathrm{~Hz}, 2 \mathrm{H}), 4.04(\mathrm{~s}, 3 \mathrm{H}) ;{ }^{13} \mathrm{C}$ NMR ठ 191.7 (4ry, C=O), 159.8 (4ry, C-2 of Ar), $136.1(\mathrm{CH}), 134.5$ (d, J = 3 Hz, 3CH, C-4 of $\mathrm{PPh}_{3}$ ), 133.9 (d, $J=11 \mathrm{~Hz}, 6 \mathrm{CH}, \mathrm{C}-2$ of $\left.\mathrm{PPh}_{3}\right), 131.0(\mathrm{CH}), 130.1\left(\mathrm{~d}, J=13 \mathrm{~Hz}, 6 \mathrm{CH}, \mathrm{C}-3\right.$ of $\left.\mathrm{PPh}_{3}\right), 120.8(\mathrm{CH}), 119.1(\mathrm{~d}$ $J=89 \mathrm{~Hz}, 3 \mathrm{C}, \mathrm{C}-1$ of $\left.\mathrm{PPh}_{3}\right), 112.3(\mathrm{CH}), 56.7(\mathrm{OMe}), 41.8\left(\mathrm{~d}, J=59 \mathrm{~Hz}, \mathrm{CH}_{2}\right) ;{ }^{31} \mathrm{P} \mathrm{NMR} \delta+21.5$.

\section{Preparation of 2-hydroxy-5-methylacetophenone 29}

To a solution of $p$-cresol $(15 \mathrm{~g}, 139 \mathrm{mmol})$ in acetic anhydride $(37.5 \mathrm{~mL})$ was added pyridine $(1.13 \mathrm{~mL})$. After $12 \mathrm{~h}$ of stirring at $25^{\circ} \mathrm{C}$, the volatiles were evaporated. The resulting oil was taken up in diethyl ether, washed with $10 \%$ aqueous sodium bicarbonate twice and brine once, and dried and evaporated to give the acetate (20.85 g, quant. yield) which was used without further purification; ${ }^{1} \mathrm{H}$ NMR $\delta 7.15$ (d, $J$ $=9 \mathrm{~Hz}, 2 \mathrm{H}, \mathrm{H}-3$ and 5), $6.95(\mathrm{~d}, J=9 \mathrm{~Hz}, 2 \mathrm{H}, \mathrm{H}-2$ and 6), 2.32 (s, 3H, OMe), 2.25 (s, 3H, Me).

To the crude ester $(20.85 \mathrm{~g}, 0.14 \mathrm{mmol})$ was added anhydrous aluminium chloride $(18.75 \mathrm{~g}, 0.14 \mathrm{mmol})$ and the mixture was heated for $1 \mathrm{~h}$ at $130{ }^{\circ} \mathrm{C}$. It was then cooled to $25^{\circ} \mathrm{C}$, treated with ice $(7.5 \mathrm{~g})$, allowed to stand for $1 \mathrm{~h}$, diluted with $\mathrm{CH}_{2} \mathrm{Cl}_{2}$, and stirred overnight. The organic phase phase was separated, dried, and evaporated to give the product $(16.63 \mathrm{~g}, 80 \%)$ as green crystals; $\mathrm{mp} 48-50{ }^{\circ} \mathrm{C}$, (lit., ${ }^{35}$ $\left.50{ }^{\circ} \mathrm{C}\right) ;{ }^{1} \mathrm{H}$ NMR $\delta 12.10$ (s, 1H, OH), 7.48 (d, $\left.J=1.8 \mathrm{~Hz}, 2 \mathrm{H}, \mathrm{H}-6\right), 7.26$ (dd, $\left.J=8.4,1.8 \mathrm{~Hz}, 1 \mathrm{H}, \mathrm{H}-4\right)$, $6.86(\mathrm{~d}, J=8.4 \mathrm{~Hz}, 1 \mathrm{H}, \mathrm{H}-3), 2.32$ (s, 3H, OMe), 2.25 (s, 2H,Me).

\section{Preparation of 2-methoxy-5-methylacetophenone 30}

Methyl iodide (5.02 mL, $80 \mathrm{mmol}$ ) was added to a stirred mixture of hydroxyacetophenone 29 (10.0 g, 67 $\mathrm{mmol})$ and anhydrous potassium carbonate $(9.19 \mathrm{~g}, 67 \mathrm{mmol})$ in dry DMF $(120 \mathrm{~mL})$, and the mixture was stirred for $18 \mathrm{~h}$ at room temperature. The solvent was removed under vacuum, water was added, and the mixture was extracted with diethyl ether. The extracts were washed well with water to remove traces of DMF, dried and evaporated to give the product which was used without further purification; ${ }^{1} \mathrm{H}$ NMR $\delta$ 
$7.53(\mathrm{~d}, J=1.8 \mathrm{~Hz}, 1 \mathrm{H}, \mathrm{H}-6), 7.24(\mathrm{dd}, J=6.31 .8 \mathrm{~Hz}, 1 \mathrm{H}, \mathrm{H}-4), 6.85(\mathrm{~d}, J=6.3 \mathrm{~Hz}, 1 \mathrm{H}, \mathrm{H}-3), 3.86(\mathrm{~s}$, 3H, OMe), 2.60 (s, 3H, COMe), 2.28 (s, 3H, ArMe).

\section{Preparation of 2-methoxy-5-methylphenacyl bromide 31}

This was prepared as for $\mathbf{2 5}$, using the crude compound $\mathbf{3 0}(18.18 \mathrm{~g}, 111 \mathrm{mmol})$ and bromine $(3.77 \mathrm{~mL}$, $73 \mathrm{mmol})$ in diethyl ether $(160 \mathrm{~mL})$, with recrystallisation from the ethanol to give the product $(11.22 \mathrm{~g}$, $42 \%$ ) as grey crystals; mp $76-78{ }^{\circ} \mathrm{C}$ (lit., $\left.{ }^{36} 77{ }^{\circ} \mathrm{C}\right) ;{ }^{1} \mathrm{H}$ NMR $\delta 7.62$ (m, 1H, H-6), 7.31 (m, 1H, H-4), 6.89 (m, 1H, H-3), 4.60 (s, 2H, $\mathrm{CH}_{2} \mathrm{Br}$ ), 3.92 (s, 3H, OMe), 2.31 (s, 3H, ArMe)

\section{Preparation of (2-methoxy-5-methylbenzoylmethyl)triphenylphosphonium bromide 32}

This was prepared as for 28, using starting material $\mathbf{3 1}$ (5.86 g, $25.6 \mathrm{mmol})$ and triphenylphosphine (6.71 $\mathrm{g}, 25.6 \mathrm{mmol})$ in toluene $(100 \mathrm{~mL})$ reacted at room temperature to give the product $(8.20 \mathrm{~g}, 63 \%)$ as colourless crystals; mp $168-170{ }^{\circ} \mathrm{C} ;{ }^{1} \mathrm{H}$ NMR $\delta 7.93-7.66(\mathrm{~m}, 15 \mathrm{H}), 7.52(\mathrm{~d}, J=2 \mathrm{~Hz}, 1 \mathrm{H}, \mathrm{H}-4$ of Ar), $7.32(\mathrm{dd}, J=8.4,2 \mathrm{~Hz}, 1 \mathrm{H}, \mathrm{H}-6$ of Ar), 6.89 (d, $J=8.4 \mathrm{~Hz}, 1 \mathrm{H}, \mathrm{H}-3$ of Ar), 6.07 (d, $J=11 \mathrm{~Hz}, 2 \mathrm{H}$, $\mathrm{CH}_{2} \mathrm{PPh}_{3}$ ), 4.01 (s, 3H, OMe), 2.25 (s, 3H, ArMe); ${ }^{13} \mathrm{C}$ NMR $\delta 191.7$ (d, $J=7 \mathrm{~Hz}, 4 \mathrm{ry}, \mathrm{CO}$ ), 157.9 (4ry, C-2 of Ar), 136.8 (CH of Ar), 134.5 (d, $J=3 \mathrm{~Hz}, 3 \mathrm{CH}, \mathrm{C}-4$ of $\mathrm{PPh}_{3}$ ), 133.9 (d, $J=10 \mathrm{~Hz}, 6 \mathrm{CH}, \mathrm{C}-2$ of $\mathrm{PPh}_{3}$ ), 131.0 (CH of Ar), 130.05 (d, $J=13 \mathrm{~Hz}, 6 \mathrm{CH}, \mathrm{C}-3$ of $\left.\mathrm{PPh}_{3}\right), 119.0\left(\mathrm{~d}, J=89 \mathrm{~Hz}, 3 \mathrm{C}, \mathrm{C}-1 \mathrm{of} \mathrm{PPh}_{3}\right)$, 112.2 (CH of Ar), $56.7(\mathrm{OMe}), 41.7\left(\mathrm{~d}, J=58 \mathrm{~Hz}, \mathrm{CH}_{2}\right), 20.1(\mathrm{ArMe}) ; ;{ }^{31} \mathrm{P} \mathrm{NMR} \delta+21.4$.

\section{Preparation of (2-methoxy-5-methylbenzoyl)methylenetriphenylphosphorane 33}

The starting phosphonium salt $32(8.2 \mathrm{~g}, 16.23 \mathrm{mmol})$ was dissolved in a saturated aq. solution of $\mathrm{Na}_{2} \mathrm{CO}_{3}$, and stirred for a few minutes. The mixture was extracted with $\mathrm{CH}_{2} \mathrm{Cl}_{2}$, which was dried and evaporated to give the crude product. This was recrystallised from the ethyl acetate to give the pure product $(5.64 \mathrm{~g}$, $82 \%$ ) as colourless crystals; $\mathrm{mp} 170-172{ }^{\circ} \mathrm{C}$; IR 1732, 1677, 1602, 1587, 1578, 1266, 1241, 1155, 1103, $1022 \mathrm{~cm}^{-1} ;{ }^{1} \mathrm{H}$ NMR $\delta 7.78-7.70(\mathrm{~m}, 7 \mathrm{H}), 7.57-7.42(\mathrm{~m}, 9 \mathrm{H}), 7.07(\mathrm{dd}, J=9,3 \mathrm{~Hz}, 1 \mathrm{H}, \mathrm{H}-4), 6.81(\mathrm{~d}, J=$ $9 \mathrm{~Hz}, 1 \mathrm{H}, \mathrm{H}-3), 4.67$ (d, $J=30 \mathrm{~Hz}, 1 \mathrm{H}, \mathrm{CH}=\mathrm{PPh}_{3}$ ), 3.86 (s, 3H, OMe), 2.27 (s, 3H, ArMe); ${ }^{13} \mathrm{C} \mathrm{NMR} \delta$ 183.6 (d, $J=2 \mathrm{~Hz}, 4 \mathrm{ry}, \mathrm{CO}), 155.4$ (4ry, C-2 of Ar), 133.1 (d, $J=10 \mathrm{~Hz}, 6 \mathrm{CH}, \mathrm{C}-2$ of $\left.\mathrm{PPh}_{3}\right), 131.7$ (d, $J=$ $2 \mathrm{~Hz}, 3 \mathrm{CH}, \mathrm{C}-4$ of $\mathrm{PPh}_{3}$ ), 131.1 (d, $J=13 \mathrm{~Hz}, 4 \mathrm{ry}, \mathrm{C}-1$ of $\left.\mathrm{Ar}\right), 130.2$ (CH of Ar), 130.0 (CH of Ar), 129.4 (4ry, C-5 of Ar), 128.6 (d, $J=12 \mathrm{~Hz}, 6 \mathrm{CH}, \mathrm{C}-3$ of $\mathrm{PPh}_{3}$ ), 127.2 (d, $J=90 \mathrm{~Hz}, 3 \mathrm{C}, \mathrm{C}-1$ of $\mathrm{PPh}_{3}$ ), 111.6 (CH of Ar), $56.1(\mathrm{OMe}), 55.1\left(\mathrm{~d}, J=107 \mathrm{~Hz}, \mathrm{CH}=\mathrm{PPh}_{3}\right), 20.3(\mathrm{Me}) ;{ }^{31} \mathrm{P}$ NMR $\delta+15.0$; HRMS: Calc for $\mathrm{C}_{28} \mathrm{H}_{26} \mathrm{O}_{2} \mathrm{P}\left(\mathrm{M}^{+}+\mathrm{H}\right): 425.1670$. Found: 425.1658 .

\section{Preparation of (cinnamoyl)(2-methoxy-5-methylbenzoyl)methylenetriphenylphosphorane 34}

A solution of the stabilised ylide $33(1.0 \mathrm{~g}, 2.37 \mathrm{mmol})$ and triethylamine $(0.24 \mathrm{~g}, 0.33 \mathrm{~mL}, 2.37 \mathrm{mmol})$ in dry toluene $(25 \mathrm{~mL})$ was stirred at room temperature while a solution of cinnamoyl chloride $(0.39 \mathrm{~g}, 2.37$ $\mathrm{mmol})$ in dry toluene $(10 \mathrm{~mL})$ was added dropwise. After the addition, the solution was stirred for $3 \mathrm{~h}$ and then poured into water. The organic phase was separated and the aqueous phase was extracted with $\mathrm{CH}_{2} \mathrm{Cl}_{2}$. The combined organic phase was dried and evaporated to give the ylide which was recrystallised 
from ethyl acetate to give the product $(0.5 \mathrm{~g}, 39 \%)$ as yellow crystals; mp $147-148{ }^{\circ} \mathrm{C}$; IR 2969,2880 , 1630, 1574, 1457, 1312, 1276, 1106, $978 \mathrm{~cm}^{-1}$; ${ }^{1} \mathrm{H}$ NMR $\delta ~ 7.82-7.72$ (m, 6H), 7.55-7.40 (m, 9H), 7.25$7.12(\mathrm{~m}, 5 \mathrm{H}), 7.127 .05(\mathrm{dd}, J=8.4,2 \mathrm{~Hz}, 1 \mathrm{H}), 7.05-6.98(\mathrm{~m}, 2 \mathrm{H}), 6.85(\mathrm{~d}, J=15.6 \mathrm{~Hz}, 1 \mathrm{H}), 6.72(\mathrm{~d}, J=$ $8.4 \mathrm{~Hz}, 1 \mathrm{H}), 3.77$ (s, 3H, OMe), 2.26 (s, 3H, OMe); ${ }^{13} \mathrm{C}$ NMR $\delta 189.9$ (d, J= $\left.8 \mathrm{~Hz}, 4 \mathrm{ry}, \mathrm{COAr}\right), 185.8$ (d, $J=6 \mathrm{~Hz}, 4 \mathrm{ry}, \underline{\mathrm{COCH}}=), 154.2$ (4ry, C-2 of Ar), 136.6 (d, $J=2 \mathrm{~Hz}, \mathrm{CHPh}$ ), 136.1 (4ry, C-1 of Ar), 133.2 $\left(\mathrm{d}, J=10 \mathrm{~Hz}, 6 \mathrm{CH}, \mathrm{C}-2\right.$ of $\left.\mathrm{PPh}_{3}\right), 131.4\left(\mathrm{~d}, J=3 \mathrm{~Hz}, 3 \mathrm{CH}, \mathrm{C}-4\right.$ of $\left.\mathrm{PPh}_{3}\right), 130.7$ (C-6 of Ar), 129.9 (4ry, C-1 of Ph), 129.6 (C-4 of Ph), $128.4\left(\mathrm{~d}, J=13 \mathrm{~Hz}, 6 \mathrm{CH}, \mathrm{C}-3\right.$ of $\left.\mathrm{PPh}_{3}\right), 128.2(2 \mathrm{C}, \mathrm{C}-3$ and $5 \mathrm{of} \mathrm{Ph})$, 127.5 (2 C, C-2 and 6 of Ph), 126.9 (d, $J=10 \mathrm{~Hz},=\underline{\mathrm{CHCO}}), 126.3$ (d, $J=92 \mathrm{~Hz}, 3 \mathrm{C}, \mathrm{C}-1$ of $\mathrm{PPh}_{3}$ ), 111.0 (C-3 of Ar), 89.8 (d, $J=102 \mathrm{~Hz}, 4 \mathrm{ry}, \mathrm{C}=\mathrm{P}), 55.6(\mathrm{OMe}), 20.3(\mathrm{Me}) ;{ }^{31} \mathrm{P} \mathrm{NMR} \delta+16.8$; $\mathrm{MS}_{\left(\mathrm{ES}^{+}\right)} \mathrm{m} / \mathrm{z}$ $576.86\left(\mathrm{M}^{+}+\mathrm{Na}, 100 \%\right)$; HRMS: Calc for $\mathrm{C}_{37} \mathrm{H}_{31} \mathrm{NaO}_{3} \mathrm{P}(\mathrm{M}+\mathrm{Na})$ : 577.1909 . Found: 577.1909.

\section{FVP of Ylide 34}

FVP of the title compound $(49.9 \mathrm{mg})$ at $750{ }^{\circ} \mathrm{C}$ and $2-3 \times 10^{-2}$ Torr gave a yellow solid at the exit of the furnace. NMR results suggested that the crude product consisted of $\mathrm{Ph}_{3} \mathrm{PO}$ as well as three different heterocyclic compounds ( $c a$. 20\% yield each), most probably: 10-methyl-12H-benzo[ $a]$ xanthen-12-one 35, 10-methylnaphtho[2,1- $b$ ]benzofuran 36 and 8-methylnaphtho[1,2-b]benzofuran 37. However despite extensive attempts, the very closely similar properties of these meant that they could not be separated or characterised fully.

\section{Preparation of 1,4-diphenyl-2-thioxo-3-(triphenylphosphoranylidene)butane-1,4-dione 40}

Triphenylphosphine $(2.36 \mathrm{~g}, 6.9 \mathrm{mmol})$ in dry toluene $(20 \mathrm{~mL})$ was rapidly added with stirring to a mixture of dibenzoylacetylene 39 (1.05 g, $3.4 \mathrm{mmol})$ and sulfur (1.42 g, $34 \mathrm{mmol})$ in dry toluene $(20 \mathrm{~mL})$. Monitoring by ${ }^{31} \mathrm{P}$ NMR indicated that the mixture contained $\mathrm{Ph}_{3} \mathrm{PS}$ and product in the ration of $4: 1$. The products were separated by chromatography on silica gel with hexane as the eluent to flush off the $\mathrm{Ph}_{3} \mathrm{PS}$ and hexane/diethyl ether $1: 1$ to elute the product $(0.88 \mathrm{~g}, 37 \%)$ as pale brown crystals; $\mathrm{mp} 106-108{ }^{\circ} \mathrm{C}$; ${ }^{1} \mathrm{H}$ NMR $\delta$ 7.94-7.06 (m, 25H); ${ }^{13} \mathrm{C}$ NMR $\delta 203.6$ (d, $\left.J=8 \mathrm{~Hz}, 4 \mathrm{ry}, \mathrm{C}=\mathrm{S}\right), 191.8$ (d, $\left.J=11 \mathrm{~Hz}, 4 \mathrm{ry}, \mathrm{C}=\mathrm{O}\right)$, $191.2(\mathrm{~d}, J=15 \mathrm{~Hz}, 4 \mathrm{ry}, \mathrm{C}=\mathrm{O}), 139.2$ (d, $J=6 \mathrm{~Hz}, 4 \mathrm{ry}, \mathrm{C}$ of Ar), 134.7 (d, $J=2 \mathrm{~Hz}, 4 \mathrm{ry}, \mathrm{C}$ of Ar), 132.8 (d, $J=10 \mathrm{~Hz}, 6 \mathrm{CH}, \mathrm{C}-2$ of $\mathrm{PPh}_{3}$ ), 132.0 (d, $J=3 \mathrm{~Hz}, 3 \mathrm{CH}, \mathrm{C}-4$ of $\mathrm{PPh}_{3}$ ), $131.8(\mathrm{CH}), 131.5(\mathrm{CH}), 129.3$ $(2 \mathrm{CH}), 129.0(2 \mathrm{CH}), 128.4\left(\mathrm{~d}, J=13 \mathrm{~Hz}, 6 \mathrm{CH}, \mathrm{C}-3\right.$ of $\left.\mathrm{PPh}_{3}\right), 127.9(4 \mathrm{CH}), 122.3$ (d, $J=92 \mathrm{~Hz}, 4 \mathrm{ry}, \mathrm{C}-1$ of $\left.\mathrm{PPh}_{3}\right), 105.8(\mathrm{~d}, J=101 \mathrm{~Hz}, 4 \mathrm{ry}, \mathrm{C}=\mathrm{P})$ [agreement with lit.,${ }^{25}$ ]; ${ }^{31} \mathrm{P} \mathrm{NMR} \delta+10.8$.

\section{FVP of Ylide 40}

FVP of the title compound $40(64.0 \mathrm{mg}, 0.12 \mathrm{mmol})$ at $750{ }^{\circ} \mathrm{C}$ and $2-3 \times 10^{-2}$ Torr gave a dark yellow solid at the exit of the furnace. The ${ }^{31} \mathrm{P}$ NMR results showed the crude product to contain a mixture of $\mathrm{Ph}_{3} \mathrm{PO}$ and $\mathrm{Ph}_{3} \mathrm{PS}$ as the only phosphorus-containing products with ratio of $1: 1.2$, implying that the other pyrolysis products were dibenzoylacetylene 39 and 1,4-diphenyl-2-thioxobut-3-yn-1-one, respectively. However in view of the disappointing selectivity, these were not separated nor their yields determined. 


\section{Preparation of 2-methoxy- $N$-phenylbenzamide 41}

To a stirred mixture of aniline $(10.9 \mathrm{~g}, 11 \mathrm{~mL}, 0.12 \mathrm{~mol})$ and $\mathrm{NaOH}(9.0 \mathrm{~g}, 0.24 \mathrm{~mol})$ in water $(90 \mathrm{~mL})$, 2-methoxybenzoyl chloride was added dropwise and the mixture was stirred vigorously for $15 \mathrm{~min}$. The product was extracted with $\mathrm{CH}_{2} \mathrm{Cl}_{2}$, which was dried and evaporated to give the crude product. This was recrystallised from ethyl acetate to give the pure product $(19.8 \mathrm{~g}, 73 \%)$ as colourless crystals; mp 75$77{ }^{\circ} \mathrm{C}$ (lit., $\left.{ }^{37} 76-77{ }^{\circ} \mathrm{C}\right) ;{ }^{1} \mathrm{H}$ NMR $\delta 8.28(\mathrm{~m}, 1 \mathrm{H}),, 7.68(\mathrm{~m}, 2 \mathrm{H}), 7.50-7.44(\mathrm{~m}, 1 \mathrm{H}), 7.38-7.32(\mathrm{~m}, 2 \mathrm{H})$, 7.14-7.09 (m, 2H), $7.01(\mathrm{~d}, J=9 \mathrm{~Hz}, 1 \mathrm{H}), 4.02$ (s, 3H, OMe) [agreement with lit., ${ }^{37}$.

\section{Preparation of 2-methoxy- $N$-phenylbenzimidoyl chloride 42}

A mixture of the starting amide $41(10 \mathrm{~g}, 44.1 \mathrm{mmol}), \mathrm{PCl}_{5}(9.1 \mathrm{~g}, 44.1 \mathrm{mmol})$ and $\mathrm{POCl}_{3}\left(2 \mathrm{~cm}^{3}\right)$ was heated under reflux for $5 \mathrm{~h}$. The products were separated by kügelrohr distillation under vacuum. At first the mixture was heated from $\mathrm{rt}$ to remove all the $\mathrm{POCl}_{3}$. When the temperature was raised to $100{ }^{\circ} \mathrm{C}$ the mixture became solid, and when the temperature was raised to $170{ }^{\circ} \mathrm{C}$, the unstable product $(3.5 \mathrm{~g}, 32 \%)$ was obtained as a yellow liquid; ${ }^{1} \mathrm{H}$ NMR $\delta$ 7.60-7.55 (m, 1H), 7.38-7.31 (m, 3H), 7.18-7.11 (m, 1H), 7.06-7.00 (m, 2H), 6.95-6.86 (m, 2H), 3.78 (s, 3H, OMe); ${ }^{13} \mathrm{C}$ NMR $\delta 159.3$ (4ry, C=N), 156.6 (4ry, C-2 of Ar), 147.1 (4ry, C of Ph), $131.8(\mathrm{CH}), 129.9(\mathrm{CH}), 128.6(2 \mathrm{CH}), 126.7(\mathrm{C}), 124.8(\mathrm{CH}), 120.1(2 \mathrm{CH})$, $120.0(\mathrm{CH}), 111.6(\mathrm{CH}), 55.7(\mathrm{OMe})$.

\section{Preparation of (2-methoxy- $N$-phenylbenzimidoyl)methylenetriphenylphosphorane 43}

To a suspension of methyltriphenylphosphonium bromide $(5.3 \mathrm{~g}, 14.8 \mathrm{mmol})$ in dry toluene $(100 \mathrm{~mL})$ at rt and under nitrogen atmosphere was added BuLi (5.9 mL, 2.5 M, $14.8 \mathrm{mmol})$ dropwise. The bright orange solution was stirred for $30 \mathrm{~min}$ to form methylenetriphenylphosphorane. To the solution was added imidoyl chloride 42 (1.7 g, $7.4 \mathrm{mmol})$, and the mixture was stirred overnight. The mixture was added to water and extracted with $\mathrm{CH}_{2} \mathrm{Cl}_{2}$. The organic layer was dried and the solvent was removed to furnish a dark red oil, which solidified with time and was recrystallised from ethyl acetate and a little $\mathrm{CH}_{2} \mathrm{Cl}_{2}$ to give the product $(0.77 \mathrm{~g}, 21 \%)$ as yellow crystals; mp $167-169{ }^{\circ} \mathrm{C}$; IR $2966,2945,1591,1509$, 1240, 1099, 1022, 890, $692 \mathrm{~cm}^{-1}$; ${ }^{1} \mathrm{H}$ NMR $\delta 7.65-7.42$ (m, 16H), 7.03-6.84 (m, 6H), 6.53-6.48 (m, 1H), $6.17(\mathrm{~d}, J=9 \mathrm{~Hz}, 1 \mathrm{H}), 3.20$ (s, 3H, OMe); ${ }^{13} \mathrm{C}$ NMR $\delta 163.5$ (d, $\left.J=14 \mathrm{~Hz}, 4 \mathrm{ry}, \mathrm{C}=\mathrm{N}\right), 155.7$ (4ry, C-2 of Ar), 139.4 (4ry, C-1 of Ar), 133.1 (d, $J=10 \mathrm{~Hz}, 6 \mathrm{CH}, \mathrm{C}-2$ of $\left.\mathrm{PPh}_{3}\right), 133.0$ (d, $J=2 \mathrm{~Hz}, 3 \mathrm{CH}, \mathrm{C}-4$ of $\left.\mathrm{PPh}_{3}\right), 131.6(\mathrm{CH}), 130.2(\mathrm{CH}), 129.1\left(\mathrm{~d}, J=13 \mathrm{~Hz}, 6 \mathrm{CH}, \mathrm{C}-3\right.$ of $\left.\mathrm{PPh}_{3}\right), 128.1(\mathrm{CH}), 123.6(\mathrm{CH}), 123.3(\mathrm{~d}$, $J=92 \mathrm{~Hz}, 3 \mathrm{C}, \mathrm{C}-1$ of $\left.\mathrm{PPh}_{3}\right), 122.2(\mathrm{CH}), 120.0(\mathrm{CH}), 110.5(\mathrm{CH}), 65.0(\mathrm{~d}, J=125 \mathrm{~Hz}, C \mathrm{H}=\mathrm{P}), 54.3$ $(\mathrm{OMe}) ;{ }^{31} \mathrm{P}$ NMR $\delta+13.7$; MS $\left(\mathrm{ES}^{+}\right) \mathrm{m} / z 486.08\left(\mathrm{M}^{+}+\mathrm{H}, 100 \%\right)$; HRMS: Calc for $\mathrm{C}_{33} \mathrm{H}_{29} \mathrm{NOP}\left(\mathrm{M}^{+}+\mathrm{H}\right)$ : 486.1987. Found: 486.1985.

\section{Preparation of (cinnamoyl)(2-methoxy- $N$-phenylbenzimidoyl)methylenetriphenylphosphorane 44}

A solution of $43(0.50 \mathrm{~g}, 1.03 \mathrm{mmol})$ and triethylamine $(0.11 \mathrm{~g}, 1.03 \mathrm{mmol})$ in dry toluene $(10 \mathrm{~mL})$ was stirred at $\mathrm{rt}$ while a solution of the cinnamoyl chloride $(0.17 \mathrm{~g}, 1.03 \mathrm{mmol})$ in dry toluene $(5 \mathrm{~mL})$ was 
added dropwise. The mixture was stirred overnight then poured into water. The organic layer was separated and the aqueous phase was extracted with $\mathrm{CH}_{2} \mathrm{Cl}_{2}$. The combined organic extracts were dried and evaporated to give a yellow oil, which solidified and was recrystallised from ethyl acetate to give the product $(0.14 \mathrm{~g}, 22 \%)$ as colourless crystals; $\mathrm{mp} 215-217^{\circ} \mathrm{C}$; IR 1634, 1274, 1101, 1011, 757, $722 \mathrm{~cm}^{-1}$; ${ }^{1} \mathrm{H}$ NMR $\delta$ 7.63-7.40 (m, 21H), 7.07-6.82 (m, 7H), 6.47-6.42 (m, 1H), 6.07-6.04 (d, J = 9 Hz, $\left.1 \mathrm{H}\right), 5.72$ (br s, 1H), 3.54 (s, 3H,OMe); ${ }^{13} \mathrm{C}$ NMR $\delta 190.3$ (d, $\left.J=4 \mathrm{~Hz}, 4 \mathrm{ry}, \mathrm{C}=\mathrm{O}\right), 169.7$ (d, $\left.J=17 \mathrm{~Hz}, 4 \mathrm{ry}, \mathrm{C}=\mathrm{N}\right)$, 154.9 (4ry, C-2 of Ar), 141.8 (4ry, C of Ph), 136.0 (4ry, C of Ph), 133.3 (d, J = $10 \mathrm{~Hz}, 6 \mathrm{CH}, \mathrm{C}-2$ of $\mathrm{PPh}_{3}$ ), $133.0\left(\mathrm{~d}, J=2 \mathrm{~Hz}, 3 \mathrm{CH}, \mathrm{C}-4\right.$ of $\left.\mathrm{PPh}_{3}\right), 132.9(\mathrm{CH}), 130.0(\mathrm{CH}), 129.2(2 \mathrm{CH}), 129.1$ (d, J = 14 Hz, 6CH, C-3 of $\left.\mathrm{PPh}_{3}\right), 128.8(\mathrm{CH}), 128.5(\mathrm{CH}), 127.9(\mathrm{CH}), 127.6(2 \mathrm{CH}), 126.5(\mathrm{CH}), 121.3(\mathrm{~d}, J=93 \mathrm{~Hz}, 3 \mathrm{C}$, C-1 of $\mathrm{PPh}_{3}$ ), 120.7 (4ry, C of Ar), $120.5(\mathrm{CH}), 110.3(\mathrm{CH}), 89.5$ (d, $\left.J=117 \mathrm{~Hz}, C=\mathrm{P}\right), 55.0(\mathrm{OMe})[2$ $\mathrm{CH}$ signals not apparent due to peak overlap]; ${ }^{31} \mathrm{P}$ NMR $\delta+17.0 ; \mathrm{MS}\left(\mathrm{ES}^{+}\right) \mathrm{m} / z 616.17\left(\mathrm{M}^{+}+\mathrm{H}, 100 \%\right)$; HRMS: Calc for $\mathrm{C}_{42} \mathrm{H}_{35} \mathrm{NO}_{2} \mathrm{P}\left(\mathrm{M}^{+}+\mathrm{H}\right)$ : 616.2405. Found: 616.2419 .

\section{FVP of Ylide 44}

FVP of the title compound $165(50 \mathrm{mg}, 0.08 \mathrm{mmol})$ at $750{ }^{\circ} \mathrm{C}$ and $2-3 \times 10^{-2}$ Torr gave a dark yellow solid at the exit of the furnace. The NMR results showed the crude pyrolysis product was a mixture of $\mathrm{Ph}_{3} \mathrm{PO}$ and 4-phenylimino-2-styryl-4H-benzopyran 45. The latter was separated using preparative TLC (hexane/diethyl ether, 9:1) as a yellow gum (11.9 mg, 46\%); ${ }^{1} \mathrm{H}$ NMR $\delta 8.42(\mathrm{~s}, 1 \mathrm{H}), 7.76-7.35(\mathrm{~m}, 11 \mathrm{H})$, 7.15-7.10 (m, 1H), $6.97(\mathrm{~d}, J=6 \mathrm{~Hz}, 2 \mathrm{H}), 6.58(\mathrm{~d}, J=15 \mathrm{~Hz}, 1 \mathrm{H}), 6.12(\mathrm{~s}, 1 \mathrm{H}) ;{ }^{13} \mathrm{C}$ NMR $\delta 167.3$ (4ry, $\mathrm{C}=\mathrm{N}), 153.7$ (4ry, C-2 of Ar), 135.4 (4ry, C), $132.3(\mathrm{CH}), 131.9(\mathrm{CH}), 131.5(\mathrm{CH}), 129.2(2 \mathrm{CH}), 128.9$ $(2 \mathrm{CH}), 128.4(\mathrm{CH}), 127.2(\mathrm{CH}), 124.9(\mathrm{CH}), 120.9(\mathrm{CH}), 117.4(\mathrm{CH}), 110.1(\mathrm{CH}), 102.1(\mathrm{CH})[4 \mathrm{C}$ were not apparent]; MS (CI) $m / z 324.14\left(\mathrm{M}^{+}+\mathrm{H}, 100 \%\right)$; HRMS : Calc for $\mathrm{C}_{23} \mathrm{H}_{18} \mathrm{NO}\left(\mathrm{M}^{+}+\mathrm{H}\right): 324.1388$. Found: 324.1395.

\section{REFERENCES}

1. L. Tietze, G. Brasche, and K. M. Gericke, 'Domino Reactions in Organic Synthesis', Wiley-VCH, Weinheim, 2006.

2. L. F. Tietze, Chem.Rev., 1996,96, 115.

3. R. A. Aitken and Y. Boubalouta, Chapter 2 in Advances in Heterocyclic Chemistry, Volume 15, ed. by E. F. V. Scriven and C. A. Ramsden, Elsevier, Oxford, 2015, 93.

4. R. A. Aitken, C. Boeters, and J. J. Morrison, Tetrahedron Lett., 1995, 36, 1303; R. A. Aitken, C. Boeters, and J. J. Morrison, J. Chem. Soc., Perkin Trans. 1, 1997, 2625.

5. R. A. Aitken, M. E. Balkovich, H. J. Bestmann, O. Clem, S. E. Gibson, and T. Röder, Synlett, 1999, 1235; R. A. Aitken, N. A. Al-Awadi, M. E. Balkovich, H. J. Bestmann, O. Clem, S. Gibson, A. Groß, A. Kumar, and Th. Röder, Eur. J. Org. Chem., 2003, 840. 
6. R. A. Aitken and G. Burns, Tetrahedron Lett., 1987, 28, 3717; R. A. Aitken and G. Burns, J. Chem. Soc., Perkin Trans. 1, 1994, 2455; R. A. Aitken, ARKIVOC, 2000, v, 798.

7. R. A. Aitken, C. K. Bradbury, G. Burns, and J. J. Morrison, Synlett, 1995, 53; R. A. Aitken, G. Burns, and J. J. Morrison, J. Chem. Soc., Perkin Trans. 1, 1998, 3937.

8. R. A. Aitken and A. N. Garnett, Synlett, 2001, 228.

9. R. A. Aitken and A. N. Garnett, New J. Chem., 2009, 33, 2402.

10. R. A. Aitken and L. Murray, J. Org. Chem., 2008, 73, 9781.

11. M. Singh, M. Kaur, and O. Silakari, Eur.J. Med. Chem., 2014, 84, 206.

12. P. A. Chopard, R. J. G. Searle, and F. H. Devitt, J. Org. Chem., 1965, 30, 1015.

13. R. A. Aitken and N. Karodia, Liebigs Ann. / Recueil, 1997, 779.

14. A. D. Malta, G. Garcia, R. Roux, B. Schoentjes, C. S. Gal, B. Tonnerre, and J. Wagnon, US Pat. 20040180878 [Chem. Abstr., 2003, 138, 137337].

15. H. Shimizu and M. Murakami, Chem. Commun., 2007, 2855.

16. Glaxo Laboratories Ltd., Fr. Pat. 1,556,822 (1969) [Chem. Abstr., 1970, 72, 66960].

17. H. J. Bestmann and B. Arnason, Chem. Ber., 1962, 95, 1513.

18. A. R. Katritzky, A. S. Vincek, and K. Suzuki, ARKIVOC, 2005, v, 116.

19. M. S. M. Ahmed and A. Mori, Org. Lett., 2003, 5, 3057.

20. D. A. Alonso, C. Najera, and M. C. Pacheco, J. Org. Chem., 2004, 69, 1615.

21. T. S. Wheeler, Org. Synth., 1952, 32, 72; Org. Synth. Coll. Vol., 1963, 4, 478.

22. A. M. B. S. R. C. S. Costa, F. M. Dean, M. A. Jones, and R. S. Varma, J. Chem. Soc., Perkin Trans. $1,1985,799$.

23. R. A. Aitken, G. Dawson, N. S. Keddie, H. Kraus, A. M. Z. Slawin, J. Wheatley, and J. D. Woollins, Chem. Commun., 2009, 7381.

24. R. A. Aitken, N. A. Al-Awadi, O. M. E. El-Dusouqui, D. M. M. Farrell, and A. Kumar, Int. J. Chem. Kinet., 2006, 38, 496.

25. J. C. Tebby, I. F. Wilson, and D. V. Griffiths, J. Chem. Soc., Perkin Trans. 1, 1979, 2133.

26. R. A. Aitken, H. Hérion, A. Janosi, N. Karodia, S. V. Raut, S. Seth, I. J. Shannon, and F. C. Smith, J. Chem. Soc., Perkin Trans. 1, 1994, 2467.

27. L. R. Falvello, J. C. Ginés, J. J. Carbó, A. Lledós, R. Navarro, T. Soler, and E. P. Urriolabeitia, Inorg. Chem., 2006, 45, 6803.

28. G. Wittig and M. Schlosser, Tetrahedron, 1962, 18, 1023.

29. P.-C. Yan, J.-H. Xie, X.-D. Zhang, K. Chen, Y.-Q. Li, Q.-L. Zhou, and D.-Q. Che, Chem. Commun., 2014, 50, 15987.

30. W. Baker, J. Chem. Soc., 1933, 1381. 
31. V. T. Ramakrishnan and J. Kagan, J. Org. Chem., 1970, 35, 2901.

32. A. Kasahara, T. Izumi, and M. Ooshima, Bull. Chem. Soc. Jpn., 1974, 47, 2526.

33. C. Zhou, A. V. Dubrovsky, and R. C. Larock, J. Org. Chem., 2006, 71, 1626.

34. E. F. Elslager and D. F. Worth, US Pat. 3,560,515 (1971) [Chem. Abstr., 1971, 74, 141910].

35. S. K. Mandal and K. Nag, J. Chem. Soc., Dalton Trans., 1983, 2429.

36. H. K. Pendse and S. D. Limaye, Rasayanam, 1955, 2, 74 [Chem. Abstr., 1956, 50, 60279].

37. L. J. Zhang, S. P. Su, H. P. Wu, and S. W. Wang, Tetrahedron, 2009, 65, 10022. 